NBER WORKING PAPER SERIES

\title{
SCHOOL SPIRIT: LEGISLATOR SCHOOL TIES AND STATE FUNDING FOR HIGHER EDUCATION
}

\author{
Aaron K. Chatterji \\ Joowon Kim \\ Ryan C. McDevitt \\ Working Paper 24818 \\ http://www.nber.org/papers/w24818 \\ NATIONAL BUREAU OF ECONOMIC RESEARCH \\ 1050 Massachusetts Avenue \\ Cambridge, MA 02138 \\ July 2018
}

This research did not receive any specific grant from funding agencies in the public, commercial, or not-for-profit sectors. We thank Denislav Bodichev and Ivan Ivanov for their outstanding data work. The views expressed herein are those of the authors and do not necessarily reflect the views of the National Bureau of Economic Research.

NBER working papers are circulated for discussion and comment purposes. They have not been peer-reviewed or been subject to the review by the NBER Board of Directors that accompanies official NBER publications.

(C) 2018 by Aaron K. Chatterji, Joowon Kim, and Ryan C. McDevitt. All rights reserved. Short sections of text, not to exceed two paragraphs, may be quoted without explicit permission provided that full credit, including $(\odot$ notice, is given to the source. 
School Spirit: Legislator School Ties and State Funding for Higher Education Aaron K. Chatterji, Joowon Kim, and Ryan C. McDevitt NBER Working Paper No. 24818

July 2018

JEL No. H0,H3,H52,H75,I23,I28

\begin{abstract}
$\underline{\text { ABSTRACT }}$
We explore a new mechanism to understand state funding for public colleges and universities by leveraging data on the educational experiences of state legislators, specifically if and where they received postsecondary education. Using novel, hand-collected data from 2002 through 2014, we provide comprehensive documentation for the first time in the literature on the educational backgrounds of state legislators. We find a statistically significant, positive association between the share of legislators who attended their states' public institutions and state funding for their entire public higher-education system. We also find a similar positive relationship between the share of state legislators who attended particular campuses of the state's public university system and funding for those campuses. This relationship is more pronounced among publicly educated legislators who represent legislative districts close to their alma mater's district, and becomes most consequential when the legislator's district contains his or her alma mater. We discuss the implications of our findings for academic studies on how politics and legislators' personal experiences in influence support for higher education.

Aaron K. Chatterji

The Fuqua School of Business

Duke University

100 Fuqua Drive, Box 90120

Durham, NC 27708

and NBER

ronnie@duke.edu

Joowon Kim

The Fuqua School of Business

Duke University

100 Fuqua Drive, Box 90120

Durham, NC 27708

jk284@duke.edu

Ryan C. McDevitt

Duke University

The Fuqua School of Business

Department of Economics

Durham, NC 27708

ryan.mcdevitt@duke.edu
\end{abstract}




\section{Introduction}

Elected representatives make important decisions about the allocation of resources across society and the provision of public goods. Prior scholarship has found legislators weigh electoral considerations and their own individual preferences in developing positions on public policy issues (Downs, 1957; Black et al., 1958; Bianco, 1994). Although elections create strong incentives for legislators to respond to the preferences of their constituents (Geer, 1996; Stimson et al., 1995), scholars have also documented that personal experiences can significantly influence legislators' political decisions (e.g., Osborne and Slivinski, 1996; Besley and Coate, 1997; Levitt, 1996; Kingdon, 1989). We know little about which kinds of personal experiences are most salient and how they are weighed in practice alongside traditional political considerations. We aim to address this open question by exploring a specific kind of personal experience, namely, if and where each state legislator in the United States received a postsecondary education, and how these school ties influence state support for higher education.

Prior work has explored the determinants of state funding for public higher education. This research has found that variation in funding across states stems from economic, demographic, and political differences across states (e.g., Archibald and Feldman, 2006; McLendon et al., 2009; Okunade, 2004; Rizzo, 2004; Toutkoushian and Hollis, 1998). However, although state legislators have the primary responsibility for budget policy in their respective states, including appropriations for higher education (Hovey, 1999), comparatively little work has explored how their personal experiences influence funding outcomes. Some limited empirical evidence shows the personal preferences of legislators can profoundly influence their views on policy (e.g., Levitt, 1996; Kingdon, 1989). Scholars have documented that legislators make decisions for reasons beyond narrow political interests, arguing that their personal convictions, experiences, and family members can influence their policy positions and votes on key legislation. For example, Washington (2006) demonstrated that legislators who have daughters are more likely to support progressive policies, particularly when the legislation relates to reproductive rights.

We adopt a related approach by investigating how state legislators' ties to colleges and uni- 
versities (hereafter, institutions) influence higher-education policy. We propose that loyalty to one's alma mater (hereafter, alumni loyalty) is the mechanism that links school ties and a greater support for higher-education funding among state legislators. Our conceptual framework draws upon group identity, which suggests one's identity or sense of self is largely based on group membership (Akerlof and Kranton, 2000; Tajfel and Turner, 1979). We emphasize the role of college education in shaping a legislator's support for higher education because a college education has been found to be a formative experience that has a lasting influence on students' sociopolitical beliefs and identity (Hyman and Wright, 1979). Whether via selection or treatment, the college experience is designed to bond alums to one another and the institution (Astin, 1977). And because group identity affects individual behavior, this dynamic can result in favoring one's own group at the expense of others, or in our context, providing preferred treatment such as more generous support for one's own alma mater by virtue of alumni loyalty (Akerlof and Kranton, 2000, 2002; Mael and Ashforth, 1992).

Although typically legislators are thought to be motivated by traditional political incentives such as maximizing their chances of reelection, we argue that a particularly influential kind of group identity develops among alums with respect to their alma mater, and that this identity ultimately influences state legislators' support for higher education. In our study, this logic would manifest in state legislators voting and lobbying colleagues for more funding for public higher education if they had attended the state's public institution themselves. Moreover, the support for higher-education funding would be greater for alums representing their alma mater's legislative districts, because alumni loyalty would be amplified by traditional political incentives to appeal to a major constituent such as a college or a university.

We systematically examine the links between state legislators' school ties and state funding for higher education by using a novel dataset that covers 96,010 legislators and their legislative districts, which contain 496 public institutions for the years 2002 through 2014. Our unique dataset allows us to provide, for the first time to our knowledge, a comprehensive description on the educational backgrounds of state legislators. First, we seek to investigate whether a statis- 
tically significant relationship indeed exists between the share of legislators who attended their states' public institutions and state funding for their entire public higher-education system. This initial step is important because considerable variation exists across states regarding the share of publicly educated legislators as well as the level of funding per full-time enrollment (FTE) (see Stylized Facts in Section 3 and Figures 1-2). We find state funding is positively associated with the share of legislators who attended their states' public institutions; one additional legislator who attended the state's public college or university is associated with a $0.5 \%$ increase in the total state funding for that state's entire public higher-education system, holding all else constant. For an average state, this increase amounts to an additional $\$ 4.9$ million in annual state funding. Furthermore, the positive relationship is more pronounced among state senators and female representatives.

Relatedly, we also observe significant variation in the allocation of state funding across individual campuses, which ranges from $\$ 1.4$ million to $\$ 891$ million for the 496 campuses in our sample. We find a statistically significant, positive relationship between the aggregated share of legislator alums from specific campuses and state funding allocated to those individual campuses (e.g., the share of California state legislators who attended University of California at Berkeley and state funding allocated solely to University of California at Berkeley). Electing one more publicly educated legislator who graduated from a given campus is associated with a $\$ 49$ million increase in annual funding allocated to that particular campus. Together, our results show publicly educated legislators are associated with not only higher levels of funding for the state's entire higher-education system, but also greater individual allocations to their alma maters.

To gain more insight into our proposed mechanism of alumni loyalty and how it complements traditional political incentives, we then explore the effect of publicly educated alums who represent the legislative district containing their alma mater. We hypothesize that (i) alumni ties to a public institution and (ii) legislative district representation have an amplifying effect on a legislator's support for higher education. We find a statistically significant, positive association between campus-level funding and alums who represent legislative districts near their alma 
mater, and this relationship becomes most pronounced when the legislator's district contains his or her alma mater. Relative to alums representing nearby districts, alumni representation of their alma maters reflects an additional 180\% increase in funding. The results of our analyses are consistent with our argument and substantiate the validity of our proposed mechanism of alumni loyalty.

In the next section, we review the relevant literature on the motivations of legislators and state funding for higher education, along with their implications for our study. In Section 3, we present several stylized facts from our novel dataset. In Section 4, we discuss our methodology and present our key findings. We conclude in Section 5.

\section{Conceptual Framework and Implications}

The traditional model of American electoral politics is that elected officials respond to public opinion (Black, 1972; Jacobs and Shapiro, 2000). That is, legislators work primarily to garner support from voters, appealing to the median voter to raise their chances of re-election (Downs, 1957; Black et al., 1958; Caselli and Morelli, 2004). For example, prior work has documented how

public opinion motivated the U.S. Congress to enact more liberal policies in the 1960s, followed by a reversal toward a more conservative course in the early 1980s, before rebounding back in the liberal direction by the late 1980s (Stimson et al., 1995). Relatedly, other work has suggested a connection between the provision of public goods and electoral motivations (e.g., Mayhew, 1974; Fiorina, 1977; Cain et al., 1987).

Aside from traditional political interests, legislators' personal beliefs, experiences, and even their children may also affect their policy decisions (Levitt, 1996; Kingdon, 1989; Bianco, 1994; Washington, 2006). This channel seems particularly likely when the personal experience is directly related to the issue at hand. For example, Senator Rob Portman of Ohio reversed his opposition to same-sex marriage in 2013, acknowledging his son's sexual orientation had influenced his view. 
An experience that could plausibly influence legislators' opinions on higher-education policy is their own educational experience. While experiences, in general, shape preferences and attitudes (Bagozzi, 1981), a college education notably represents a crucial developmental time for students during which their sociopolitical orientation is most malleable (Hyman and Wright, 1979). Various social experiences during this time, in addition to the leniency to freely experiment with differing social roles, ultimately beget stronger bonds among alums and alumni loyalty (Astin, 1977; Mael and Ashforth, 1992; Pascarella and Terenzini, 2005). Consequently, alums are more likely to identify with one another and their alma mater, relative to unrelated individuals and schools (Tajfel and Turner, 1979; Akerlof and Kranton, 2000, 2002). These social ties can strengthen the incentive for legislators to support their alma mater and fellow alums, not only for personal benefits, but also to give back to the school that made a lasting difference in their own life. Thus, a loyal alum is more likely to donate generously and provide resources to the institution (Arrow, 1972; Steinberg, 1987; Ade et al., 1994; Clotfelter, 2003; Mael and Ashforth, 1992).

One insight from the work on group identity is that once people identify themselves as a group member, they adopt behaviors that are aligned with the group's norms (Akerlof and Kranton, 2000, 2002, 2008). In turn, group identity affects individual behavior (Akerlof and Kranton, 2000), which often leads to intergroup discrimination such as enhanced cooperation (e.g., Goette et al., 2006) or greater affection and trust (e.g., Brewer, 1979) between members belonging to the same group than between those from unrelated groups or isolated individuals. Prior work suggests alums are more likely to support their own alma mater than to support other schools because their beliefs and behavior are influenced by alumni loyalty (Akerlof and Kranton, 2002; Miller et al., 1981; Tajfel and Turner, 1979; Landa, 1994). For an alum, continued affiliation with the alma mater offers a source of prestige and identity, as well as an opportunity to provide support of various kinds, including donations and voluntary participation in events (Simon, 1993; Mael and Ashforth, 1992).

Although altruism, social desirability, career advancement, and expectations of respect have 
been suggested as possible motives (e.g., Piliavin and Charng, 1990), the activities of loyal alums could also be explained as a form of payment in exchange for intangible rewards such as personal gratification and enhancing the value of their degree (Andreoni, 1990; Akerlof and Kranton, 2000), or even a sense of obligation to provide goods and services in return (Rose-Ackerman, 1996). As such, some studies have suggested alums may represent the most important financiers of colleges and universities through their direct donations (e.g., Mael and Ashforth, 1992). In our case, we would expect legislators to vote and lobby colleagues for more funding for public higher education if they had attended their state's public institution themselves.

To date, the literature on higher-education financing has primarily focused on aggregate determinants at the state level, including political characteristics, economic and demographic conditions, and higher-education policies (e.g., Archibald and Feldman, 2006; McLendon et al., 2009; Okunade, 2004; Rizzo, 2004; Toutkoushian and Hollis, 1998). More recent work on political ideology has delved into the relationship between higher-education funding and partisan control of the legislature, whereby Democratic and Republican Parties hold polarized preferences around taxation and spending on public services such as education and healthcare (Alt and Lowry, 2000; Barrilleaux et al., 2002), and some empirical research suggests the Democratic Party control of the legislature may favorably influence higher-education funding (Archibald and Feldman, 2006; McLendon et al., 2009). Similarly, some scholars have argued female politicians are more supportive of issues related to public services such as poverty, education, and health (e.g., Sapiro, 1983; Rosenwasser and Seale, 1988; Carroll, 1994; Saint-German, 1989), though empirical studies on higher-education funding have not yet rigorously examined the effect of gender, to our knowledge.

Gubernatorial power represents another important source of political influence, which varies considerably across states. For instance, a select group of states afford their governors significant power via broader appointment privileges, line-item vetoes, and no term limits ${ }^{5}$ (Dometrius, 1987;

\footnotetext{
5 Twelve states have no gubernatorial term limits: Connecticut, Idaho, Illinois, Iowa, Massachusetts, Minnesota, New York, North Dakota, Texas, Utah, Washington, and Wisconsin.
} 
Beyle, 2003); however, empirical evidence linking gubernatorial power to funding outcomes is also limited. Lastly, state governments have different political ideologies along the liberal-conservative continuum (Berry et al., 1998). For example, states with more liberal politicians may have a greater affinity for supporting public services and providing more funding for public education.

Notwithstanding a growing body of literature evaluating the determinants of higher-education funding, previous work has not considered how legislators' individual experiences shape funding

decisions. In this paper, we explore whether one salient type of personal experience, namely, if and where each U.S. state legislator received a postsecondary education, is associated with state funding of higher education.

\section{Data and Stylized Facts}

We examine novel biographical data on state legislators, documenting whether they received any postsecondary education and the specific campus from which they graduated. We partition our analyses by two distinct units of analysis - State System and Campus. The former evaluates the impact of state legislators' school ties on state funding of their respective states' entire public higher-education system (hereafter, system state funding), whereas the latter examines the impact of school ties on the specific allocation of state funding to each campus (hereafter, campus state funding). In our data, an example of a state system would be all of the public institutions in the state of Wisconsin, whereas University of Wisconsin at Madison would be an example of a campus.

\subsection{State System Data}

Our state-level dataset is built from multiple secondary sources on each state's economic, demographic, educational, and political environment for the period 2002 through 2014 (see Table 1). Economic and demographic variables include population estimates, unemployment rates, gross state product (GSP), and tax revenue from the previous year. Education variables consist of FTE, total tuition at public institutions, and bachelor's degree attainment rate aggregated at 
the state level. Given that each state's funding is constrained by its available resources, funding should be positively associated with GSP and tax revenue from the previous year. Conversely, higher unemployment rates should lead to lower funding as state governments anticipate weaker economies in subsequent years (Strathman, 1994). Likewise, factors such as enrollment and tuition influence funding. The enrollment share of out-of-state students should be negatively related to funding, because public institutions have been aggressively recruiting non-resident students to compensate for funding cuts. A recent study reported that a $10 \%$ drop in state funding was associated with a $2.7 \%$ increase in out-of-state enrollment for public institutions between 2002 and 2013 (Jaquette and Curs, 2015). Taken together, we control for population, tuition, FTE, GSP, bachelor's attainment rate, and unemployment rate because many economic and demographic conditions likely shape higher-education funding (McLendon et al., 2009; Okunade, 2004).

State funding for higher education occurs through a multi-stage process. The appropriations bill for a given state, which is a legislative motion that authorizes state spending such as funding for higher education, is customarily introduced by the legislature subsequent to the governor's budget proposal. Although in some states each chamber drafts its own version of the appropriations bill, most states give this responsibility solely to the lower house based on the idea that spending proposals should originate from those legislators closest to the voters (The Councils of State Governments, 2002; Hutchison and James, 1988). ${ }^{6}$ The bill is then amended and each chamber votes on it, with a conference committee resolving any differences between the two. Finally, the governor may sign, sign with a line-item veto, or veto the entire bill; however, the extent of gubernatorial power and the specific budgeting process differ considerably across states (Dometrius, 1987; Hutchison and James, 1988; Squire and Hamm, 2005).

Although we examined individual legislative votes, most voting records on amendments leading up to a state's final appropriations bill are not available. For example, North Carolina's

\footnotetext{
6 All U.S. state governments are modeled after the federal government with three branches - executive, legislative, and judicial - serving as a system of checks and balances. All but one state, Nebraska, have a bicameral legislature made up of two chambers: a smaller upper house (i.e., the Senate) and a larger lower house with relatively shorter terms (i.e., the House of Representatives, the Assembly, or the House of Delegates).
} 
Appropriations Act of 2007 (House Bill 1473) was introduced in early March. This bill was amended later that month to include two bills that would increase funding for the North Carolina Research Campus (NCRC) in Kannapolis (S1050 and H1375) and revised once again to include funding for the University of North Carolina expansion (S1069), but no electronic records of legislative votes on these amendments exist. Another challenge in studying voting outcomes is the prevalence of partisan voting (Bartels, 2000). Between 2009 and 2011 in North Carolina, for instance, both the Senate and the House reflected party-line votes on the Appropriations Bill. In 2009, the Senate had 27 Ayes (all Republicans) and 18 Noes (all Democrats), with 65 Ayes (all Republicans) and 52 Noes (all Democrats) in the House. In 2011, the Senate had 31 Ayes (all Republicans) and 19 Noes (all Democrats), with 72 Ayes (four Democrats) and 47 Noes (all Democrats) in the House. Such stability in partisan voting patterns over time has been widely documented (e.g., Peltzman, 1985; Bronars and Lott Jr, 1997; Bender and Lott Jr, 1996). As a result, we use the share of alumni legislators aggregated at the state level, a measure described in more detail below.

For our main variable of interest, we categorize the educational background data of each legislator and governor into one of seven mutually exclusive types of institutions, which are then aggregated as percentages at the state level: in-state public, in-state private, in-state community, out-of-state public, out-of-state private, out-of-state community, and no college education. Our primary data source for the educational backgrounds of legislators is Vote Smart, which is a nonpartisan, non-profit organization that collects information on candidates for public office across six areas: background, voting records, campaign finances, issue positions, interest-group ratings, and public statements (Vote Smart, 2016). We supplement Vote Smart's biographical data of state legislators with our independent data-collection effort because Vote Smart's educational backgrounds data is deprecated with inaccurate entries for more than $25 \%$ of sampled legislators and missing data for approximately 13\%. For instance, the entire biographical section for numerous legislators was missing in some early years of the dataset. Other examples of data issues include incorrect or vague labeling of the campus location for multi-campus universities (e.g., 
"University of North Carolina" instead of "University of North Carolina at Greensboro"), or missing the obtained degree for those who attended multiple institutions (i.e., the undergraduate institution where one received a bachelor's degree is not specified). We therefore cross-checked the Vote Smart dataset by searching each legislator online to validate and/or update his or her educational background using sources such as Ballotpedia (a non-partisan, non-profit political encyclopedia), LinkedIn, and state government and personal campaign websites. We also used the State Legislative Election Returns dataset to obtain the most accurate list of elected legislators for each year (ICPSR studies 3938, 8907 and 21480; Klarner et al., 2015).

Our final sample for the State System Analyses contains 96,010 legislators across all 50 states for the years 2002 through 2014. From this sample, we document several notable descriptive statistics on the educational backgrounds of legislators. These data represent an important contribution of our work in and of themselves because they have not been previously documented in the literature, to our knowledge. We find the average four-year college-degree-attainment rate is $87.3 \%$ for state senators and $81.6 \%$ for state representatives. ${ }^{7}$ Furthermore, $7.9 \%$ of senators and $12.7 \%$ of representatives did not receive any postsecondary education. Considerable variation exists across states in the share of legislators with four-year postsecondary education (see Figures 1 and 2). The New Hampshire legislature has the highest average share of legislators without postsecondary education (39\%), followed by Arkansas (37\%), South Dakota (33\%), Montana (26\%), Maine (25\%), Kansas (24\%), and New Mexico (18\%). ${ }^{8}$ The members in the House of Representatives drive New Hampshire's high rate. At 400 seats, the largest lower chamber of all U.S. State Legislatures, only 57\% of New Hampshire state representatives received postsecondary education from four-year institutions, with more than half having attended out-of-state

\footnotetext{
7 Percentages in this section are not weighted. The total number of seats in each state's legislature (i.e., number of senators and representatives combined) is used as the denominator. Variables using weighted means are italicized in the next section (e.g., in-state public).

8 States with a high average rate of no postsecondary education in the Senate: South Dakota at 26\%, Arkansas at $24 \%$, Iowa at $22 \%$, Montana at $19 \%$, Maine at $17 \%$, New Hampshire at $16 \%$.

States with a high average rate of no postsecondary education in the House of Representatives: New Hampshire at $40 \%$, South Dakota at $36 \%$, Kansas at $28 \%$, Montana at $28 \%$, Maine at $27 \%$, Vermont at $27 \%$, New Mexico at $24 \%$, Arizona at $19 \%$, Delaware at $18 \%$, Colorado at $17 \%$, Kentucky at $16 \%$.
} 
Table 1: State-Level Variable Description

\begin{tabular}{|c|c|c|c|}
\hline Variable & Description & Year & Source \\
\hline Any Institution & $\begin{array}{l}\text { Weighted mean percentage of legislators who attended any } \\
\text { higher-education institution }^{\dagger}\end{array}$ & $2002-2014$ & $\begin{array}{l}\text { Vote Smart, } \\
\text { (Klarner et al., 2015) }\end{array}$ \\
\hline Any In-State & $\begin{array}{l}\text { Weighted mean percentage of legislators who attended any } \\
\text { in-state institution }\end{array}$ & $2002-2014$ & $\begin{array}{l}\text { Vote Smart, } \\
\text { (Klarner et al., 2015) }\end{array}$ \\
\hline In-State Public & $\begin{array}{l}\text { Weighted mean percentage of legislators who attended any } \\
\text { in-state public institution }\end{array}$ & $2002-2014$ & $\begin{array}{l}\text { Vote Smart, } \\
\text { (Klarner et al., 2015) }\end{array}$ \\
\hline In-State Private & $\begin{array}{l}\text { Weighted mean percentage of legislators who attended any } \\
\text { in-state private institution }\end{array}$ & $2002-2014$ & $\begin{array}{l}\text { Vote Smart, } \\
\text { (Klarner et al., 2015) }\end{array}$ \\
\hline In-State Community & $\begin{array}{l}\text { Weighted mean percentage of legislators who attended any } \\
\text { in-state community institution }\end{array}$ & $2002-2014$ & $\begin{array}{l}\text { Vote Smart, } \\
\text { (Klarner et al., 2015) }\end{array}$ \\
\hline Any Out-Of-State & $\begin{array}{l}\text { Weighted mean percentage of legislators who attended any } \\
\text { out-of-state institution }\end{array}$ & $2002-2014$ & $\begin{array}{l}\text { Vote Smart, } \\
\text { (Klarner et al., 2015) }\end{array}$ \\
\hline Out-Of-State Public & $\begin{array}{l}\text { Weighted mean percentage of legislators who attended any } \\
\text { out-of-state public institution }\end{array}$ & $2002-2014$ & $\begin{array}{l}\text { Vote Smart, } \\
\text { (Klarner et al., 2015) }\end{array}$ \\
\hline Out-Of-State Private & $\begin{array}{l}\text { Weighted mean percentage of legislators who attended any } \\
\text { out-of-state private institution }\end{array}$ & $2002-2014$ & $\begin{array}{l}\text { Vote Smart, } \\
\text { (Klarner et al., 2015) }\end{array}$ \\
\hline Out-Of-State Community & $\begin{array}{l}\text { Weighted mean percentage of legislators who attended any } \\
\text { out-of-state community institution }\end{array}$ & $2002-2014$ & $\begin{array}{l}\text { Vote Smart, } \\
\text { (Klarner et al., 2015) }\end{array}$ \\
\hline Republican & Weighted mean percentage of Republican legislators & $2002-2014$ & $\begin{array}{l}\text { Vote Smart, } \\
\text { (Klarner et al., 2015) }\end{array}$ \\
\hline Female & Weighted mean percentage of female legislators & $2002-2014$ & $\begin{array}{l}\text { Vote Smart, } \\
\text { (Klarner et al., 2015) }\end{array}$ \\
\hline Governor In-State Public & $\begin{array}{l}\text { Binary variable indicating whether the governor attended an } \\
\text { in-state public institution }\end{array}$ & $2002-2014$ & Vote Smart \\
\hline Governor Republican & $\begin{array}{l}\text { Binary variable indicating whether the governor is a Republi- } \\
\text { can }\end{array}$ & $2002-2014$ & Vote Smart \\
\hline System State Funding & $\begin{array}{l}\text { Total state funding for all in-state higher-education institu- } \\
\text { tions in } 2014 \text { constant dollars (adjusted for cost of living, in- } \\
\text { flation, and cost of enrollment) }\end{array}$ & $2002-2014$ & SHEEO Grapevine \\
\hline Tuition & $\begin{array}{l}\text { Net tuition for public institutions by state in } 2014 \text { constant } \\
\text { dollars (adjusted for cost of living, inflation, and cost of en- } \\
\text { rollment) }\end{array}$ & $2002-2014$ & SHEEO Grapevine \\
\hline FTE & $\begin{array}{l}\text { Full-Time Equivalent (FTE) estimates for public or commu- } \\
\text { nity institutions by state }\end{array}$ & $2002-2014$ & SHEEO Grapevine \\
\hline Tax Revenue & $\begin{array}{l}\text { Total tax revenue from the previous year by state in } 2014 \\
\text { constant dollars (adjusted for cost of living and inflation) }\end{array}$ & $2002-2014$ & US BEA \\
\hline GSP & $\begin{array}{l}\text { Gross state product from the previous year in } 2014 \text { constant } \\
\text { dollars (adjusted for cost of living and inflation) }\end{array}$ & $2002-2014$ & US BEA \\
\hline State Budget & $\begin{array}{l}\text { Total expenditure budget by state in } 2014 \text { constant dollars } \\
\text { (adjusted for cost of living and inflation) }\end{array}$ & $2002-2014$ & US Census \\
\hline Bachelor's Attainment Rate & $\begin{array}{l}\text { Bachelor's degree (4-year) attainment rate from the previous } \\
\text { year by state }\end{array}$ & $2002-2014$ & US Census \\
\hline Unemployment Rate & Unemployment rate from the previous year by state & $2002-2014$ & US Census \\
\hline Population & Population estimate by state & $2002-2014$ & US Census \\
\hline
\end{tabular}




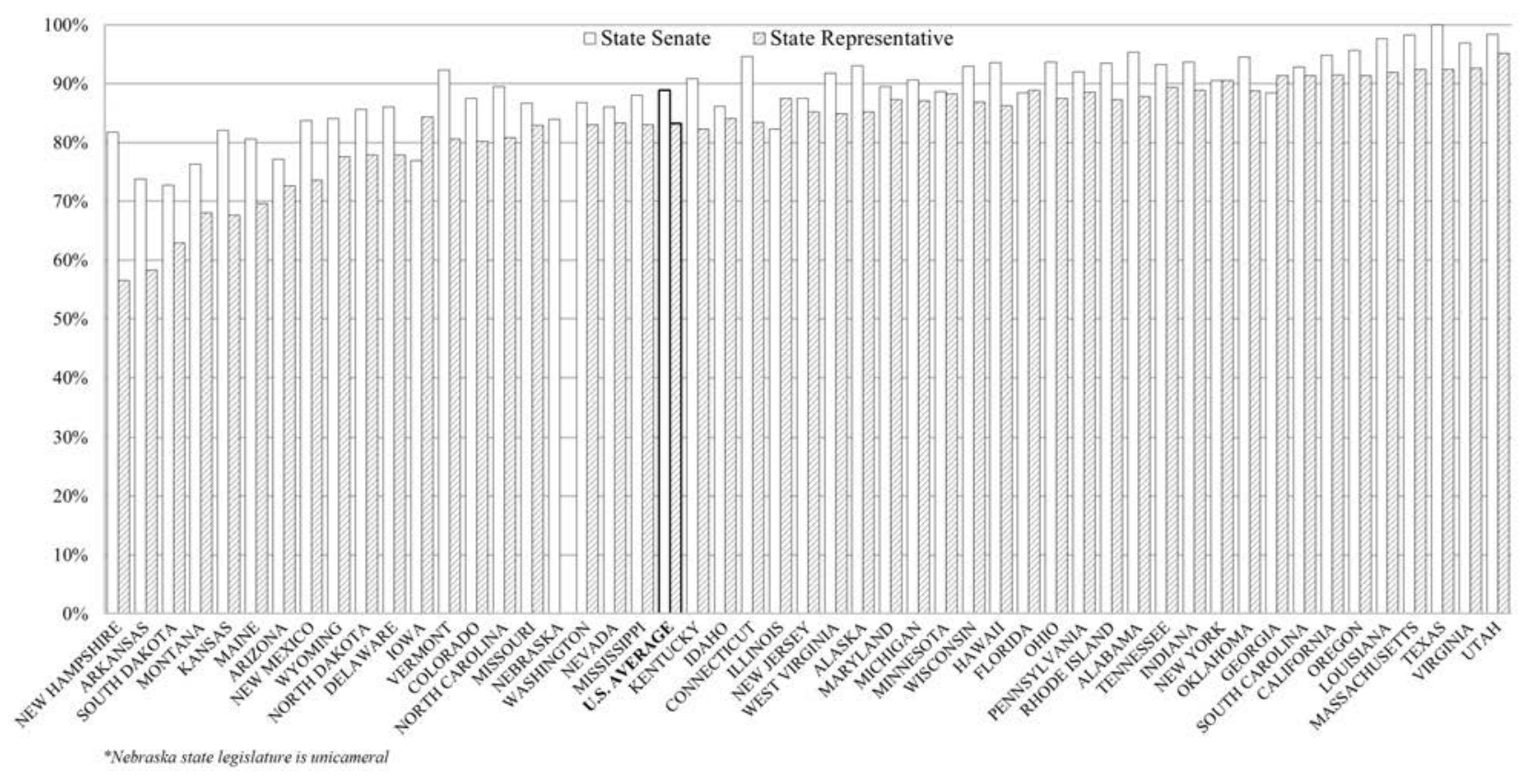

Figure 1: Legislators Who Attended Any 4-Year Institutions

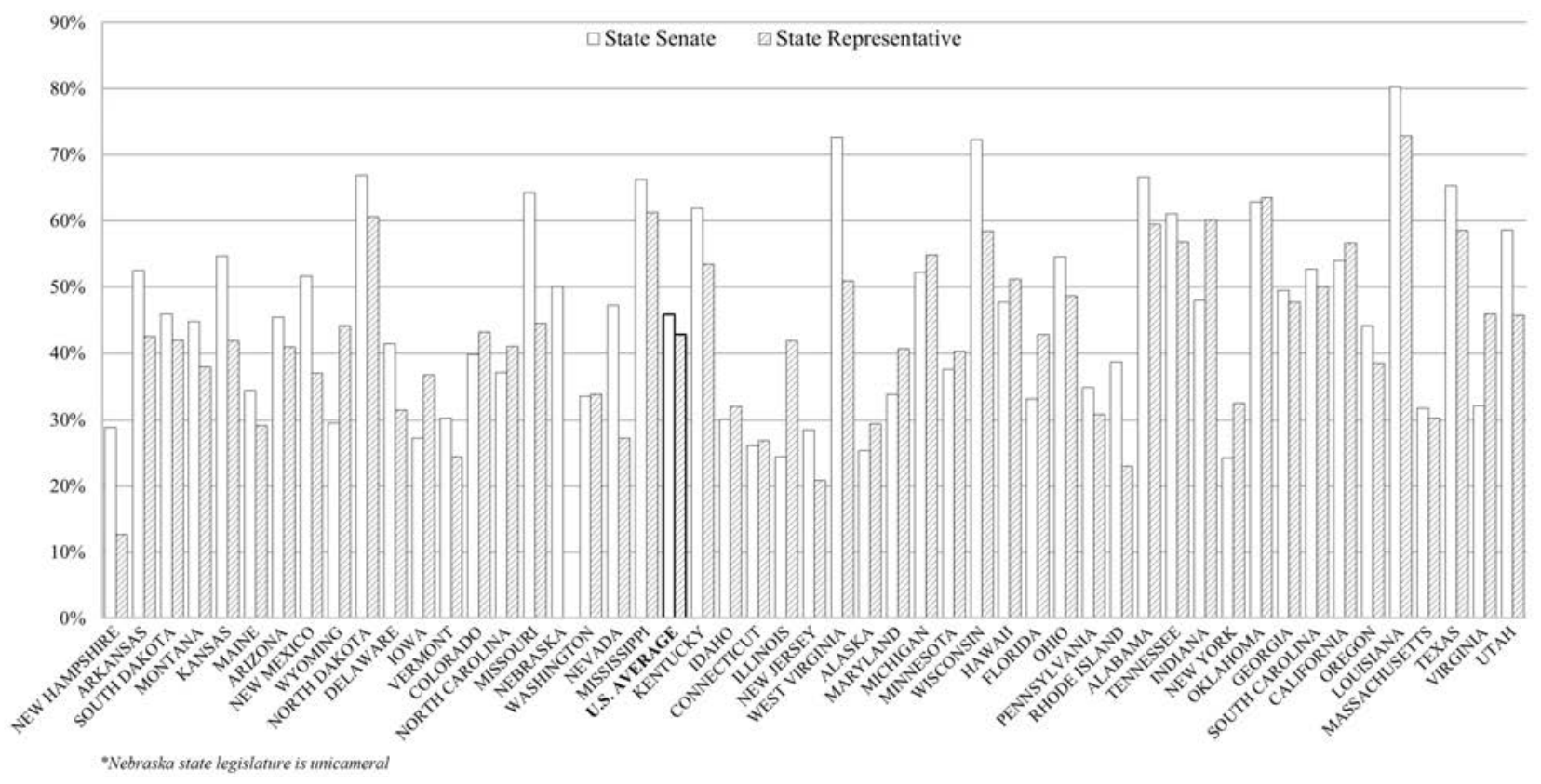

Figure 2: Legislators Who Attended In-State Public 4-Year Institutions 
institutions (or $13.7 \%$ out-of-state public and 23.5\% out-of-state private). By contrast, in South Dakota, $79 \%$ of college-educated legislators attended in-state institutions, $74 \%$ of which were public institutions (or $43.3 \%$ in-state public and $9.2 \%$ in-state private).

For the State System Analyses, we obtained the dependent variable — system state funding from SHEEO Grapevine at the Center for the Study of Education Policy and Illinois State University (SHEEO, 2014). It reflects all tax funds appropriated for higher-education annual operating expenses within each state, which covers any public institution, including public twoyear colleges and community colleges. We use the log transformation of our dependent variable given its highly skewed distribution and the low likelihood of extreme values. State funding and tuition are adjusted to constant 2014 dollars by cost of living, inflation, and enrollment mix. The enrollment-mix index reflects interstate differences in higher-education accessibility, accounting for the number of public institutions and the cost per FTE. Political variables include the share of Republican and female legislators, the presence of a Republican governor, and whether the governor attended an in-state public institution.

Our main independent variable for the State System Analyses — in-state public - represents the weighted mean percentage of state senators and representatives who attended in-state public four-year institutions, where we used the number of legislative seats for the weights. For example, the Colorado General Assembly (Colorado state legislature) is composed of 100 seats in total, with 35 members for the Senate and 65 for the House. In 2010, 51\% of senators (18 out of 35) and $48 \%$ of representatives (31 out of 65 ) had school ties to four-year public institutions in Colorado. The weighted mean accounting for the number of seats is then calculated as $48 \% \cdot(35 / 100)+51 \%$. $(65 / 100)=50 \%$. As opposed to an aggregate percentage across both chambers, a weighted mean percentage more accurately captures differences in institutional powers. Senators hold superior voting power, because the size of the lower chamber is, on average, roughly three times larger than that of the upper (i.e., mean of 39 senators vs. mean of 108 representatives). ${ }^{9}$ We believe

\footnotetext{
9 All our results are robust to alternative specifications of the main independent variable, including equal weights between the two chambers (e.g., in-state public $=0.5^{*}[$ in-state public $U H]+0.5^{*}[$ in-state public LH]) and no
} 
this weighted measure is the best indicator available of alumni influence in state legislatures. We also split our main independent variable by chamber - in-state public LH (lower house) and in-state public UH (upper house) — to disentangle the effect of voting power. Consequently, some of our State System Analyses exclude Nebraska because of its unique unicameral, nonpartisan legislature (Huber et al., 2001).

A broader measure of our main independent variable — in-state public or community — similarly represents the weighted mean percentage of state legislators who attended in-state public or community colleges at the state level. We include either public four-year institutions or community colleges in this measure because state appropriations for higher education also extends to two-year colleges.

\subsection{Campus Data}

We used the Integrated Postsecondary Education Data System (IPEDS) for our campus-level data on 496 public institutions covering the same period between 2002 through 2014 (see Table 2). Although the United States currently has over 700 active public institutions in the U.S., our balanced panel for the Campus Analyses is restricted to 496 institutions that reported financial data to IPEDS every year. Here, we focus on a more direct tie between alums and each public institution's campus unlike the aggregated state-level analyses in State System Analyses. In this case, the thought experiment is if publicly educated legislators positively influence the total state funding for their respective state's entire public higher-education system, is each campus benefiting commensurately? As such, multi-campus universities are not aggregated in these analyses and are instead observed independently by campus (e.g., University of North Carolina at Chapel Hill and University of North Carolina at Greensboro are recorded as two distinct observations rather than consolidating the entire University of North Carolina system all together). The main independent variable for this analysis - in-state public campus alum - represents the weighted

distinction by chamber (e.g., in-state public $=$ [share of legislators who attended any in-state public institutions] / [total number of legislators across both legislative chambers]). 
mean percentage of state senators and representatives who attended a specific campus of an in-state public institution (e.g., the share of California state legislators with alumni ties to University of California at Berkeley given the dependent variable of state funding for the Berkeley Campus), where we used the number of legislative seats to construct the weights, analogous to the method detailed in State System Data. The remaining share of legislators who attended other campuses of any in-state public institutions is represented by the second independent variable, in-state public other campus alum (e.g., the share of California state legislators with alumni ties to University of California at Los Angeles given the dependent variable of state funding for the Berkeley Campus). Note these two independent variables - in-state public campus alum and in-state public other campus alum - are mutually exclusive and together represent the total share of legislators who attended any in-state public institutions in a given state (i.e., in-state public from the State System Analyses).

The dependent variable - campus state funding - reflects all tax funds appropriated for an individual campus within each state, except grants and contracts. Although from different sources, system state funding is in essence an aggregated measure of campus state funding for a given state. As in the State System Analyses, we use the log transformation of our dependent variable, given its highly skewed distribution and unlikely extreme values.

Our final sample for the Campus Analyses includes 496 campuses across 49 states that covers 41 flagships and 135 research-oriented institutions (based on Carnegie Classification I). Control variables for each campus include net assets (i.e., the excess of the assets over liabilities or the residual interest in the assets remaining after liabilities are deducted; changes in net assets result from revenues, expenses, gains, and losses), expenses for academic and institutional support, revenues from tuition and fees, grants provided by federal and state agencies, and district-level population estimates. All financial variables such as net assets are adjusted to 2014 constant dollars by cost of living and inflation.

To gain more insight into our proposed mechanism of alumni loyalty, we explored the effect of alums who represent the district containing their alma mater, in-district public campus alum (e.g., 
University of North Carolina at Chapel Hill alum who represented University of North Carolina at Chapel Hill's legislative district). We hypothesize that the influence of (i) alumni ties to a public institution and (ii) legislative district representation could have a complementary effect on a legislator's support for higher-education funding. This amplification results from coupling one's alumni loyalty with traditional political incentives to appeal to a major constituent such as a college or a university.

In subsequent analyses, we introduce three main independent variables categorized according to whether a campus's legislative district was represented by an alum, whether a campus's nearby legislative districts were represented by an alum, and the remaining share of alums representing other districts in a state. Thus, the three independent variables, (i) in-district campus alum, (ii) nearby-district campus alum, and (iii) other-district campus alum, are intended to measure (i) the share of alums representing the campus's legislative district, (ii) the share of alums representing legislative districts near their alma mater's district, and (iii) the share of all remaining alums in a state unaccounted by the previous two independent variables. We define nearby districts as those that are adjacent to the campus's legislative district while located in the same city and within 10 miles of the institution. We apply these restrictions because large cities such as Chicago are divided among more than 20 legislative districts. With our definition, on average, we find two nearby districts for the Senate and three for the House (see Table 2 for additional variable descriptions). These variables are intended to explicitly capture (i) the additive effect of alumni loyalty and the political incentives of district representation, (ii) alumni loyalty without the political incentives, and (iii) relatively weaker alumni loyalty without the political incentives that arise from geographic remoteness to one's alma mater.

Descriptive statistics of variables are presented in Table 3, and Tables D and E provide the correlation matrix. We find positive correlations between system state funding and in-state public $(0.15, p<0.001)$, in-state community $(0.12, p<0.002)$, and in-state public or community $(0.17, p<0.001)$. By contrast, the share of legislators with ties to any out-of-state institutions, any out-of-state, is negatively correlated with system state funding $(0.21, p<0.001)$. Likewise, at 
the campus level, campus state funding is positively correlated with alums representing their alma mater's legislative district, in-district campus alum $(0.16, p<0.001)$, and alums representing districts that are close to the main campus of their alma mater, nearby-district campus alum $(0.12, p<0.001)$ 
Table 2: Campus-Level Variable Description

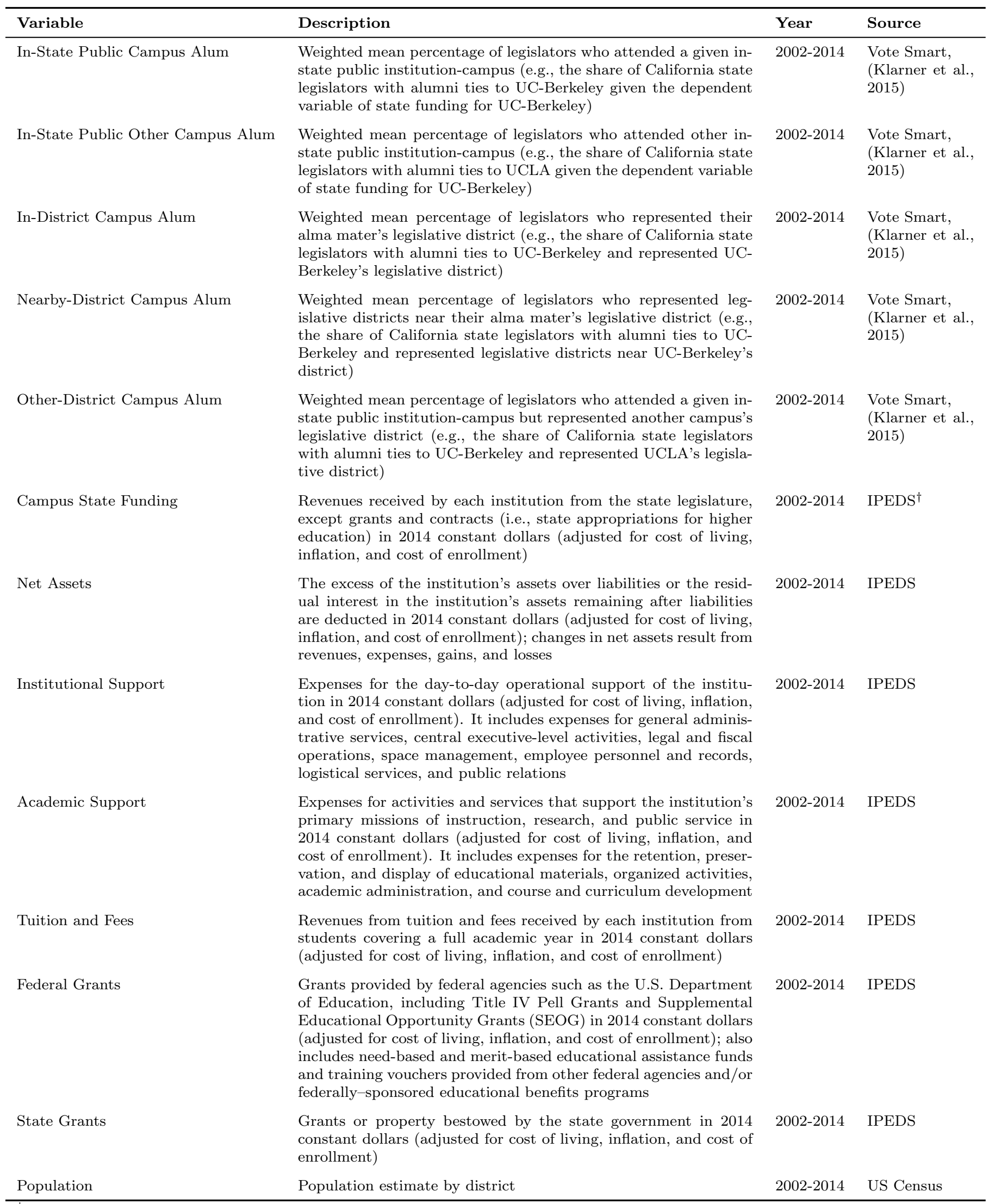

\footnotetext{
${ }^{\dagger}$ The Integrated Postsecondary Education Data System; https://nces.ed.gov/ipeds/
} 
Table 3: Summary Statistics

\begin{tabular}{|c|c|c|c|c|c|}
\hline Variable & Obs. & Mean & S.D. & Min & Max \\
\hline Any Institution & $650^{\dagger}$ & 0.88 & 0.09 & 0.50 & 0.98 \\
\hline Any In-State & 650 & 0.62 & 0.15 & 0.18 & 0.90 \\
\hline In-State Public & 650 & 0.45 & 0.14 & 0.21 & 0.80 \\
\hline In-State Private & 650 & 0.15 & 0.11 & 0.00 & 0.50 \\
\hline In-State Community & 650 & 0.03 & 0.03 & 0.00 & 0.13 \\
\hline Any Out-Of-State & 650 & 0.27 & 0.12 & 0.06 & 0.60 \\
\hline Out-Of-State Public & 650 & 0.13 & 0.08 & 0.01 & 0.44 \\
\hline Out-Of-State Private & 650 & 0.14 & 0.09 & 0.02 & 0.47 \\
\hline Out-Of-State Community & 650 & 0.00 & 0.01 & 0.00 & 0.04 \\
\hline Republican* & 637 & 0.50 & 0.17 & 0.07 & 0.90 \\
\hline Female & 650 & 0.22 & 0.08 & 0.04 & 0.53 \\
\hline Governor In-State Public & 650 & 0.38 & 0.49 & 0.00 & 1.00 \\
\hline Governor Republican & 650 & 0.53 & 0.50 & 0.00 & 1.00 \\
\hline System State Funding & 650 & $\$ 1.59 \mathrm{~B}$ & $\$ 1.92 \mathrm{~B}$ & $\$ 0.07 \mathrm{~B}$ & $\$ 12.34 \mathrm{~B}$ \\
\hline Tuition & 650 & $\$ 0.96 \mathrm{~B}$ & $\$ 0.91 \mathrm{~B}$ & $\$ 0.05 \mathrm{~B}$ & $\$ 5.09 \mathrm{~B}$ \\
\hline FTE & 650 & $0.21 \mathrm{M}$ & $0.24 \mathrm{M}$ & $0.02 \mathrm{M}$ & $1.62 \mathrm{M}$ \\
\hline Tax Revenue & 650 & $\$ 15.24 \mathrm{~B}$ & $\$ 17.89 \mathrm{~B}$ & $\$ 1.16 \mathrm{~B}$ & $\$ 122.19 \mathrm{~B}$ \\
\hline GSP & 650 & $\$ 303.32$ B & $\$ 356.58 \mathrm{~B}$ & $\$ 23.13 \mathrm{~B}$ & $\$ 2,030.27 \mathrm{~B}$ \\
\hline State Budget & 650 & $\$ 37.12 \mathrm{~B}$ & $\$ 42.38 \mathrm{~B}$ & $\$ 3.71 \mathrm{~B}$ & $\$ 264.38 \mathrm{~B}$ \\
\hline Population & 650 & $6.06 \mathrm{M}$ & $6.69 \mathrm{M}$ & $0.50 \mathrm{M}$ & $38.80 \mathrm{M}$ \\
\hline Bachelor's Attainment Rate & 650 & 0.27 & 0.05 & 0.15 & 0.41 \\
\hline Unemployment Rate & 650 & 0.06 & 0.02 & 0.03 & 0.15 \\
\hline In-State Public Campus Alum & $6,448^{\ddagger}$ & 0.04 & 0.06 & 0.00 & 0.50 \\
\hline In-State Public Other Campus Alum & 6,448 & 0.45 & 0.15 & 0.00 & 0.80 \\
\hline In-District Campus Alum & 6,448 & 0.00 & 0.01 & 0.00 & 0.05 \\
\hline Nearby-District Campus Alum & 6,448 & 0.00 & 0.01 & 0.00 & 0.17 \\
\hline Other-District Campus Alum & 6,448 & 0.03 & 0.06 & 0.00 & 0.50 \\
\hline Campus State Funding & 6,448 & $\$ 86.61 \mathrm{M}$ & $\$ 104.98 \mathrm{M}$ & $\$ 1.39 \mathrm{M}$ & $\$ 890.94 \mathrm{M}$ \\
\hline Net Assets & 6,448 & $\$ 424.37 \mathrm{M}$ & $\$ 921.19 \mathrm{M}$ & $\$-131.67 \mathrm{M}$ & $\$ 12,442.88 \mathrm{M}$ \\
\hline Institutional Support & 6,448 & $\$ 25.95 \mathrm{M}$ & $\$ 30.16 \mathrm{M}$ & $\$ 0.57 \mathrm{M}$ & $\$ 306.84 \mathrm{M}$ \\
\hline Academic Support & 6,448 & $\$ 26.85 \mathrm{M}$ & $\$ 42.99 \mathrm{M}$ & $\$ 0.09 \mathrm{M}$ & $\$ 536.38 \mathrm{M}$ \\
\hline Tuition and Fees & 6,448 & $\$ 78.92 \mathrm{M}$ & $\$ 107.28 \mathrm{M}$ & $\$ 0.03 \mathrm{M}$ & $\$ 993.98 \mathrm{M}$ \\
\hline Federal Grants & 6,448 & $\$ 55.45 \mathrm{M}$ & $\$ 103.63 \mathrm{M}$ & $\$ 0.00 \mathrm{M}$ & $\$ 1,176.14 \mathrm{M}$ \\
\hline State Grants & 6,448 & $\$ 6.83 \mathrm{M}$ & $\$ 15.51 \mathrm{M}$ & $\$ 0.00 \mathrm{M}$ & $\$ 289.99 \mathrm{M}$ \\
\hline Population & 6,448 & 568,416 & $1.20 \mathrm{M}$ & 7154 & $10.11 \mathrm{M}$ \\
\hline
\end{tabular}


Overall, legislative school ties to in-state institutions, including both public and private, are relatively higher in the Midwest $(77.4 \%)$ and South $(74.8 \%)$ than in the West $(59.3 \%)$ and Northeast (58.8\%). The share of legislators who attended two-year community colleges, either in state or out of state (and without any record of having attended a four-year institution), is similar across the four regions, with an average of $4.3 \%, 4.1 \%, 3.6 \%$, and $2.5 \%$ in the West, Midwest, South, and Northeast, respectively. Interstate mobility for legislators who attended community colleges is very low. Of all community college ties, 84.7\%, 88.4\%, 89.8\%, and 79.3\% were in-state ties for each region, respectively.

For legislators who attended out-of-state institutions, the three regions other than the Northeast reflect a near 50/50 divide between public and private. Of all ties to out-of-state institutions, $53.1 \%$ were pubic institutions in the West, $48.2 \%$ in the Midwest, and $51.5 \%$ in the South. In the Northeast, however, $70.8 \%$ of all out-of-state ties were private institutions, whereas only $29.2 \%$ were public. The divergence in the Northeast could stem from both the clustering of states in the region and the preponderance of private institutions.

Because prior work has argued that female politicians may be more predisposed to supporting public services (Sapiro, 1983; Rosenwasser and Seale, 1988), we measure the share of female legislators across the West, Midwest, South, and Northeast, where the average is 27.7\%, 22.6\%, $18.4 \%$, and $25.7 \%$, respectively. The relatively higher share of female legislators in the West is more evident for politically liberal states such as Colorado (36.7\%), Washington (33.2\%), Hawaii $(30.7 \%)$, and California (28.5\%). By contrast, several politically conservative states in the South rank among the lowest in female legislative representation: South Carolina (10.\%), Alabama (11.8\%), Mississippi (14.1\%), Louisiana (14.9\%), and Tennessee (17.5\%). We also classify states based on the outcomes of past presidential elections, where conservative states are defined as those carried by the Republican in each of the past four presidential elections $(2000,2004,2008$ and 2012), and vice versa for liberal states. We have 22 conservative states and 18 liberal 
states based on this classification, ${ }^{10}$ and the liberal states elected more female legislators than conservative states, averaging $26.6 \%$ against $17.3 \%$.

The share of Republican legislators, as expected, is higher in conservative states, at 54.9\%, than liberal states' $38.5 \%$. Of the seven states where the average share of Republicans exceeds $70 \%$, only one state, New Hampshire, is categorized as liberal. ${ }^{11}$ We find no meaningful differences in education across parties: $83.9 \%$ of Republican legislators attended four-year institutions compared to $86.1 \%$ of Democrats with analogous school ties. And by chamber, we find $88.5 \%$ for Republican senators and $90.5 \%$ for Democratic senators, compared to $82.5 \%$ and $84.7 \%$ for Republican and Democratic representatives, respectively. The two parties have statistically identical shares of legislators with school ties to in-state institutions, at $58.1 \%$. The preceding descriptive analysis shows regional patterns in legislative school ties that are consistent with accessibility of higher education in a state, including the number of institutions and interstate mobility. We also observe similar trends in school ties by gender and by party affiliation across the four regions in the United States.

Many of these descriptive statistics are the first of their kind in the literature, providing background information on the politicians responsible for funding the nation's colleges and universities. In the following section, we consider the relationship between legislators' school ties and state funding with regressions that control for differences in states' economic, demographic, political, and educational environments.

\footnotetext{
${ }^{10}$ Conservative states include Alaska, Alabama, Arkansas, Arizona, Georgia, Idaho, Kansas, Kentucky, Louisiana, Missouri, Mississippi, Montana, North Dakota, Nebraska, Oklahoma, South Carolina, South Dakota, Tennessee, Texas, Utah, West Virginia, and Wyoming.

Liberal states include California, Connecticut, Delaware, Hawaii, Illinois, Massachusetts, Maryland, Maine, Michigan, Minnesota, New Jersey, New York, Oregon, Pennsylvania, Rhodes Island, Vermont, Washington, and Wisconsin.

${ }^{11}$ Seven states with the highest share of Republican legislators: Idaho at $79.5 \%$, Indiana at $70.7 \%$, Kansas at $74.8 \%$, North Dakota at 72.6\%, New Hampshire at 72.6\%, Oklahoma at 72.5\%, South Dakota at $73.4 \%$, Tennessee at $72.7 \%$, Utah at $74.8 \%$, and Wyoming at $76.9 \%$.
} 


\section{Methodology and Results}

\subsection{State System Analyses}

To test the relationship between school ties and state funding of the public higher-education system, we regress the log of system state funding for state $i$ in year $t$ on the share of legislators with in-state college ties: ${ }^{12}$

$$
\text { System State Funding } \text { it }=\alpha_{0}+\alpha_{1}(\text { School Ties })_{i t}+\alpha_{2}(\text { Controls })_{i t}+\epsilon_{i t} \text {. }
$$

For our main specification, we employ fixed-effects regression models in which the unit of observation is a state-year. The year fixed effect controls for unobserved characteristics that affect all states uniformly within a given year (e.g., economic conditions in the United States), whereas the state fixed effect controls for unobserved state characteristics that affect funding conditions consistently over time (e.g., a state-specific budgeting process or a time-invariant favorability towards higher education). Note this specification is particularly conservative, because including a set of state and year fixed effects means our main parameter of interest is identified solely by variation in the educational experiences of legislators within a state over time, and any fixed unobserved confound — such as voters' persistent preference for public goods in a state — is differenced out. For all of our analyses, we standardize each independent variable by subtracting the mean and dividing by the standard deviation to allow for an easier interpretation and comparison of the parameter estimates.

In Table 4, the main dependent variable - system state funding - is regressed on the main variable of interest, in-state public. Along with state and year fixed effects, we control for the

\footnotetext{
${ }^{12}$ An alternative specification is to regress state-level per-capita funding on seven mutually exclusive school ties: in-state public, in-state private, in-state community, out-of-state public, out-of-state private, out-of-state community, and no college education. Saturating the specification with seven categories introduces considerable multicollinearity (because shares naturally sum to one), pushing up our standard errors. As a result, none of the individual coefficients is statistically significant when simultaneously tested with state and year fixed effects, although they are jointly significant and signs are in the expected direction with positive coefficients for in-state public and negative for out-of-state public (see Table B). We therefore focus our analysis on the coarser category of in-state higher education, rather than the finer categorization.
} 
share of Republicans, the share of female legislators, the governor's characteristics, GSP, tax revenue, bachelor's attainment rate, unemployment rate, tuition, and FTE. ${ }^{13}$ We cluster our standard errors by state for System State Analyses and by campus for Campus Analyses to account for serial correlation among variables within a state or a campus, respectively (Hoechle et al., 2007). In other words, we cluster standard errors by either state or campus based on the type of variation we wish to leverage (i.e., within-state variations for System State Analyses and within-campus variations for Campus Analyses), which improves the accuracy of our prediction by emphasizing variations across clustered groups, because the data are independent across clusters but not within (Petersen, 2009; Cameron and Miller, 2015).

We present our state-level results in Table 4. Specification 1 of Table 4 is our most restrictive specification that includes our main controls, state and year fixed effects, and clustering of standard errors by state. Here, we regress the log of system state funding on in-state public and find a positive and statistically significant relationship between school ties and funding. A one-standard-deviation increase in in-state public is associated with a $4.8 \%$ increase in system state funding. This result suggests that electing one more legislator who attended an in-state public institution is associated with a $0.5 \%$, or $\$ 4.9$ million, increase in funding given the average legislature size of 148 members.

We replicate Specification 1 in Specification 2 by legislative chamber, in-state public UH, and in-state public LH, and our results are largely consistent. In Specification 2, which is our most restrictive specification, the relationship is more pronounced among state senators who attended in-state public institutions (i.e., in-state public UH or the upper legislative chamber), which is not surprising given their greater influence on voting. For state senators, a one-standarddeviation increase in in-state public $U H$ is associated with a $4.2 \%$ increase in system state funding.

\footnotetext{
${ }^{13}$ An important assumption in the fixed-effect specification is that no correlation exists between the time-varying component in the error term and the independent variables. Though our main results are less pronounced when employing a state fixed effect, it is necessary to obtain unbiased estimates as our Lagrange multiplier test of random effects shows a strong correlation among residuals within each state (Breusch and Pagan, 1980). Because both random and fixed-effect specifications are significant, we also conducted a Hausman test of strict exogeneity to confirm a fixed-effect specification remains unbiased and consistent (Hausman, 1978).
} 
Considering the average senate size of 39 members, our results imply an addition of one state senator who attended an in-state public institution is associated with a $1.5 \%$, or $\$ 14.2$ million, increase in state funding. We find that a greater share of female legislators is associated with higher funding. The coefficient, however, is only statistically significant in the lower chamber. A one-standard-deviation increase in female $\mathrm{LH}$ is associated with a $3.4 \%$ increase in system state funding. Put differently, an addition of one female representative from the average female representation of $24 \%$ in the House is associated with a state funding increase of $1.8 \%$, or $\$ 17.1$ million. 
Table 4: The Effect of Legislators with Ties to In-State Public Institutions on System State Funding

\begin{tabular}{|c|c|c|}
\hline DV: $\log$ (System State Funding) & (1) & $(2)$ \\
\hline In-State Public & $\begin{array}{l}0.0482^{* *} \\
(0.0207)\end{array}$ & \\
\hline In-State Public UH & & $\begin{array}{l}0.0423^{* *} \\
(0.0189)\end{array}$ \\
\hline In-State Public LH & & $\begin{array}{c}0.0147 \\
(0.0225)\end{array}$ \\
\hline Republican & $\begin{array}{c}0.0247 \\
(0.0198)\end{array}$ & \\
\hline Republican UH & & $\begin{array}{c}0.0118 \\
(0.0179)\end{array}$ \\
\hline Republican LH & & $\begin{array}{c}0.0174 \\
(0.0221)\end{array}$ \\
\hline Female & $\begin{array}{c}0.0116 \\
(0.0119)\end{array}$ & \\
\hline Female UH & & $\begin{array}{c}0.00369 \\
(0.0107)\end{array}$ \\
\hline Female LH & & $\begin{array}{l}0.0335^{* *} \\
(0.0148)\end{array}$ \\
\hline Governor In-State Public & $\begin{array}{c}-0.00956 \\
(0.00698)\end{array}$ & $\begin{array}{c}-0.00915 \\
(0.00635)\end{array}$ \\
\hline Governor Republican & $\begin{array}{c}-0.00625 \\
(0.00657)\end{array}$ & $\begin{array}{c}-0.00765 \\
(0.00639)\end{array}$ \\
\hline Controls & Yes & Yes \\
\hline Year FE & Yes & Yes \\
\hline State FE & Yes & Yes \\
\hline Err. Clustered by State & Yes & Yes \\
\hline No. of Observations & 650 & 637 \\
\hline No. of States & 50 & 49 \\
\hline Adjusted- $\mathrm{R}^{2}$ & 0.994 & 0.994 \\
\hline
\end{tabular}

We find similar results for in-state public or community, a broader measure of in-state public, where funding is positively linked to the weighted mean share of legislators who attended instate public or community colleges (see Table A). In addition, we find a negative relationship between funding and legislators who attended out-of-state institutions (see Table B). Lastly, we check whether the positive effect on state funding for higher education changes after the Great Recession, as the average state funding per capita has declined substantially by $\$ 42.1$ in the period after the Great Recession, compared to an increase of $\$ 14.2$ during the preceding years 
(e.g., Figure 3). Specification 3 of Table 5 shows the effect is much stronger in the years following the Great Recession, where a one-standard-deviation increase in in-state public is associated with a $5.8 \%$ rise in system state funding, relative to a $1.0 \%$ gain indicated prior to the Great Recession. Likewise, electing one more senator with ties to an in-state public institution translates into an increase of $2.0 \%$, or $\$ 19.0$ million, relative to $0.39 \%$, or $\$ 3.7$ million, in the earlier period. These results are consistent with the notion that public school ties among state legislators helped protect public institutions from the most severe funding cuts during the Great Recession.

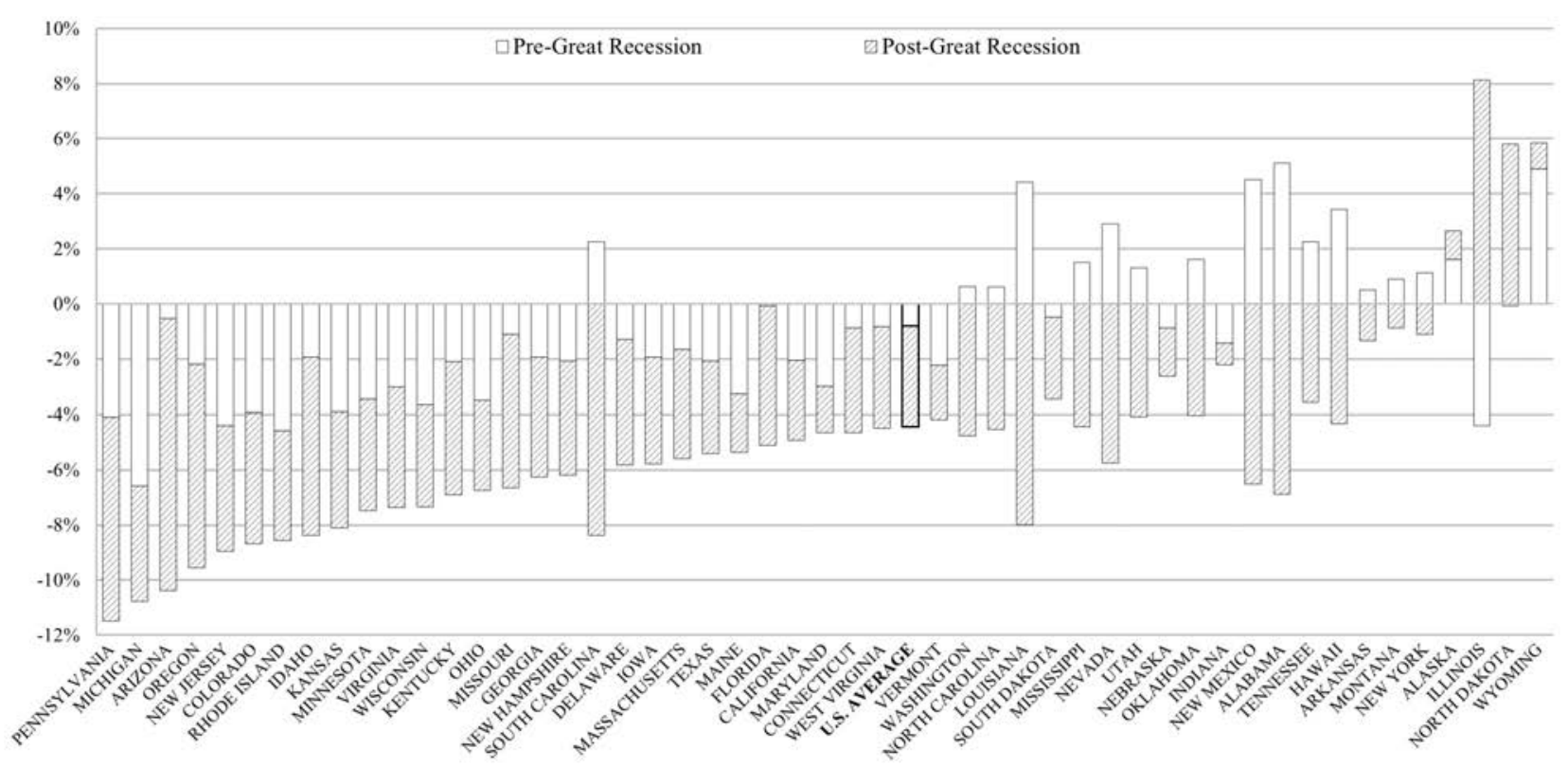

Figure 3: System State Funding per FTE Average Annual Growth Rate Pre vs. Post The Great Recession 
Table 5: The Effect of Legislators with Ties to In-State Public Institutions on System State Funding Pre vs. Post The Great Recession

\begin{tabular}{|c|c|c|c|c|}
\hline \multirow[b]{2}{*}{ DV: $\log$ (System State Funding) } & \multicolumn{2}{|c|}{ Pre-Great Recession } & \multicolumn{2}{|c|}{ Post-Great Recession } \\
\hline & (1) & $(2)$ & $(3)$ & $(4)$ \\
\hline In-State Public & $\begin{array}{c}0.0101 \\
(0.0227)\end{array}$ & & $\begin{array}{c}0.0582^{* *} \\
(0.0219)\end{array}$ & \\
\hline In-State Public UH & & $\begin{array}{c}0.0110 \\
(0.0210)\end{array}$ & & $\begin{array}{l}0.0568^{* * *} \\
(0.0172)\end{array}$ \\
\hline In-State Public LH & & $\begin{array}{c}0.0109 \\
(0.0213)\end{array}$ & & $\begin{array}{c}-0.00351 \\
(0.0287)\end{array}$ \\
\hline Republican & $\begin{array}{c}0.0278 \\
(0.0234)\end{array}$ & & $\begin{array}{c}0.0202 \\
(0.0201)\end{array}$ & \\
\hline Republican UH & & $\begin{array}{c}0.0218 \\
(0.0229)\end{array}$ & & $\begin{array}{c}0.0240 \\
(0.0174)\end{array}$ \\
\hline Republican LH & & $\begin{array}{c}0.0104 \\
(0.0266)\end{array}$ & & $\begin{array}{c}-0.00608 \\
(0.0182)\end{array}$ \\
\hline Female & $\begin{array}{c}0.0134 \\
(0.0142)\end{array}$ & & $\begin{array}{c}0.0414^{*} \\
(0.0226)\end{array}$ & \\
\hline Female UH & & $\begin{array}{r}0.00367 \\
(0.0135)\end{array}$ & & $\begin{array}{c}0.0311^{*} \\
(0.0183)\end{array}$ \\
\hline Female LH & & $\begin{array}{l}0.0374^{* * *} \\
(0.0132)\end{array}$ & & $\begin{array}{c}0.00744 \\
(0.0200)\end{array}$ \\
\hline Governor In-State Public & $\begin{array}{c}-0.00630 \\
(0.00892)\end{array}$ & $\begin{array}{c}-0.00831 \\
(0.00874)\end{array}$ & $\begin{array}{c}-0.00551 \\
(0.00905)\end{array}$ & $\begin{array}{c}-0.00586 \\
(0.00934)\end{array}$ \\
\hline Governor Republican & $\begin{array}{c}-0.00485 \\
(0.00832)\end{array}$ & $\begin{array}{c}-0.00703 \\
(0.00772)\end{array}$ & $\begin{array}{c}0.00607 \\
(0.00940)\end{array}$ & $\begin{array}{c}0.00541 \\
(0.00908)\end{array}$ \\
\hline Controls & Yes & Yes & Yes & Yes \\
\hline Year FE & Yes & Yes & Yes & Yes \\
\hline State FE & Yes & Yes & Yes & Yes \\
\hline Err. Clustered by State & Yes & Yes & Yes & Yes \\
\hline No. of Observations & 350 & 343 & 350 & 343 \\
\hline No. of States & 50 & 49 & 50 & 49 \\
\hline Adjusted- $\mathrm{R}^{2}$ & 0.997 & 0.997 & 0.995 & 0.995 \\
\hline
\end{tabular}

Standard errors in parentheses; ${ }^{*} p<0.1,{ }^{* *} p<0.05,{ }^{* * *} p<0.01$

Controls include GSP, tax revenue, bachelor's attainment rate, unemployment rate, tuition, and FTE. Standardized variables used for all analyses.

Nebraska state legislature is unicameral and thus not included for columns $(2,4)$ 


\subsection{Campus Analyses}

This section of our study entails two distinct analyses to explore complementarity between alumni loyalty and traditional political incentives: (i) testing the relationship between state legislators' school ties to specific public campuses and the allocation of state funding to those campuses, and (ii) testing the relationship between legislative district representation by publicly educated alums and the allocation of funding for their alma mater. The main specification at the campus level uses a series of control variables, including the campus's net assets, expenses for academic and institutional support, revenues from tuition and fees, grants provided by federal and state agencies, and district-level population estimates (see Table 2 for variable descriptions). A campus fixed effect is added to control for unobserved institutional characteristics that affect a given school's funding consistently over time (e.g., institutional quality, flagships, research-oriented), along with year fixed effects. Standard errors are clustered by campus to address concerns over serial correlation. Analogous to State System Analyses, we standardize each independent variable by subtracting the mean and dividing by the standard deviation to allow for an easier interpretation and comparison of the parameter estimates.

For the first analysis that examines the relationship between state legislators' school ties to specific campuses and the allocation of state funding to those campuses, we regress the log of campus state funding for campus $i$ in state $j$ in year $t$ on the share of legislators who attended a specific campus, in-state public campus alum, while controlling for the remaining share of publicly educated legislators in a state, in-state public other campus alum:

$$
\text { Campus State Funding } i_{i j t}=\beta_{0}+\beta_{1}(\text { Campus Alums })_{i j t}+\beta_{2}(\text { Controls })_{i j t}+\mu_{i j t} .
$$

Column 1 of Table 6 presents our most restrictive model that includes campus and year fixed effects with all controls and standard errors clustered by campus. We find a positive and statistically significant association between alums (i.e., in-state public campus alum) and 
funding for their alma mater. As expected, the coefficient magnitude of in-state public campus alum is statistically different from and much larger than that of in-state public other campus alum $(F=5.02, p<0.026)$. Here, a one-standard-deviation increase in in-state public campus alum is associated with a $13.8 \%$ increase in campus state funding. This means that an addition of one more legislator who graduated from a given public campus is associated with a $\$ 49$ million increase in annual funding allocated to that particular campus. These results are consistent with the notion that while in-state public institution alums show greater support for state funding of higher education broadly, this positive effect is much more consequential when it relates to funding for the particular campus they attended as a student.

Table 6: The Effect of Legislators with Ties to In-State Public Campuses on Campus State Funding

\begin{tabular}{|c|c|c|}
\hline DV: $\log$ (Campus State Funding) & (1) & $(2)$ \\
\hline In-State Public Campus Alum & $\begin{array}{c}0.138^{* *} \\
(0.0612)\end{array}$ & \\
\hline In-State Public Other Campus Alum & $\begin{array}{r}0.00470 \\
(0.0147)\end{array}$ & \\
\hline In-District Campus Alum & & $\begin{array}{l}1.816^{* *} \\
(0.756)\end{array}$ \\
\hline Nearby-District Campus Alum & & $\begin{array}{c}0.0138^{*} \\
(0.00732)\end{array}$ \\
\hline Other-District Campus Alum & & $\begin{array}{c}0.00424^{*} \\
(0.00223)\end{array}$ \\
\hline Controls & Yes & Yes \\
\hline Year FE & Yes & Yes \\
\hline Campus FE & Yes & Yes \\
\hline Err. Clustered by Campus & Yes & Yes \\
\hline No. of Observations & 6448 & 6448 \\
\hline No. of Campuses & 496 & 496 \\
\hline Adjusted-R ${ }^{2}$ & 0.984 & 0.984 \\
\hline
\end{tabular}

Finally, we dive deeper into our proposed mechanism of alumni loyalty by exploring the effect of alums who represent the legislative district containing their alma mater, in-district campus alum. We hypothesize that (i) alumni ties to a public institution and (ii) legislative district representation could have an amplifying effect on a legislator's support for higher-education funding 
by coupling one's alumni loyalty and political incentives. In column 2 of Table 6, we regress the log of campus state funding on the main independent variable, in-district campus alum, with our main controls, campus and year fixed effects, and standard errors clustered by campus. We find a positive and statistically significant relationship between funding and those representing their alma mater's legislative district, in-district campus alum. Relatedly, a statistically significant, positive association is also observed between nearby-district campus alum and campus state funding. The coefficient of in-district campus alum is statistically larger than that of nearbydistrict campus alum $(F=5.70, p<0.018)$, which is consistent with the latter being motivated by alumni loyalty without political incentives and the former being motivated by both forces. The estimates suggest alums representing their alma mater's legislative district, relative to those representing nearby districts, result in an additional $180 \%$ in state funding for their alma mater. As expected, the remaining share of alums in a state representing other legislative district, otherdistrict campus alum, show a statistically significant and positive association with funding for their alma maters.

In sum, we observe a statistically significant, positive relationship between the share of state legislators who attended in-state public institutions and the total state funding for their respective state's public higher-education system (Table 4), as well as funding allocated for their specific alma mater (column 1 of Table 6). In column 2 of Table 6 , we gain insight into both the campusspecific effect and traditional political incentives, with results supporting our hypothesis about the complementary effect of alumni loyalty and the desire for garnering constituent support. Together, our findings corroborate the validity of our proposed mechanism of alumni loyalty. ${ }^{14}$

\footnotetext{
${ }^{14}$ In the Appendix, we consider an instrumental variable (IV) regression to mitigate some concerns regarding endogeneity and omitted-variable bias by leveraging exogenous changes in legislative district boundaries cause by redistricting. While the test statistic ensures the maximum bias to be less than $10 \%$ (Staiger and Stock, 1994), our instrument may not be completely exogenous, thus yielding unreliable estimates, because the IV estimates are much larger than the OLS estimates. See Appendix for detailed discussion.
} 


\section{Discussion}

The role of public funding in higher education has recently become a contentious issue in the United States. Declining state support has compelled public institutions to pursue alternative sources of revenue (Goldin and Katz, 1998; Ehrenberg, 2006). Average state funding, which fell to as little as $10 \%$ of total institutional revenues for some states, has necessitated large increases in tuition, with the national average tuition at four-year institutions rising by more than $36 \%$ since 2004 (Ehrenberg, 2006). In most states, tuition consumes more than $15 \%$ of the state median household income, whereas it takes up less than $10 \%$ of the median household income in only five states (Hiltonsmith and Draut, 2014).

These trends call for new insights into the determinants of public funding for higher education. In examining the factors that drive a state's commitment to higher-education funding, our analyses confirm and reinforce the importance of economic, demographic, political, and policy conditions as key determinants of state funding for higher education. Notably, however, our study also highlights that the personal experiences of state legislators, specifically educational backgrounds, are important predictors of funding outcomes.

We provide empirical evidence that state legislators' school ties are positively related to state funding for higher education. Specifically, we find a statistically significant, positive association between the share of legislators who attended their states' public institutions and state funding for those states' entire public higher-education system. Although McClendon et al. (2009) similarly find a positive link between appropriation committee members' schools ties and university funding, we are able to demonstrate a broader relationship between the proportion of alumni politicians in the entire legislature and funding levels. In addition, our panel data allow us to explore variation within states over time. This feature is important because we find differences in our effect before and after the Great Recession. Further, we observe significant changes in the incidence of school ties and funding per FTE across states over time (see Figures 1-3). For instance, the share of legislators with ties to in-state public institutions increased for 24 states. By state, the standard deviation for the year-over-year change in in-state public ties ranges from 


\section{$0.3 \%$ to $8 \%$.}

Finally, our more-detailed data also allow us to consider heterogeneity among alums whose legislative districts include their alma mater, with which we can show complementarity between political incentives and alumni loyalty in shaping legislative support for state funding of higher education. Consistent with the expectation that alumni loyalty and traditional political incentives may have an additive effect on a legislator's support for higher education, we find a statistically significant, positive relationship between the share of state legislators who attended specific campuses of the state's public system and funding for those individual campuses. This relationship is more pronounced among publicly educated legislators who represent legislative districts close to their alma mater's district, which becomes most consequential when the legislator's district contains his or her alma mater. Our results consistently bolster the ultimate conclusion: public colleges and universities that have alums who represent their legislative district receive more state funding.

In sum, our findings accord with the notion that alums will have strong ties to their alma mater and are more likely to provide personal support (e.g., Akerlof and Kranton, 2000; Mael and Ashforth, 1992; Ade et al., 1994). However, our study has important limitations. We do not distinguish between the different kinds of social experiences legislators might have had in college (e.g., membership in a fraternity or on a sports team), whether the legislator benefited financially through scholarships, or whether the legislator maintains on-going ties with public institutions. In future research, scholars could also collect legislator-level data on committee membership and campaign contributions to more precisely account for the effect of other kinds of political interests on the link between publicly educated state legislators and state funding for higher education. In this spirit, a key implication from our work is that future studies on the political economy of higher-education funding should not only include a comprehensive list of political variables, but also carefully account for the personal experiences of legislators. 


\section{References}

Ade, A., Wunnava, P. V., Walsh Jr, R., 1994. Charitable giving of alumni: micro-data evidence from a large public university. American Journal of Economics and Sociology, 73-84.

Akerlof, G. A., Kranton, R. E., 2000. Economics and identity. The Quarterly Journal of Economics 115 (3), 715-753.

Akerlof, G. A., Kranton, R. E., 2002. Identity and schooling: Some lessons for the economics of education. Journal of economic literature 40 (4), 1167-1201.

Akerlof, G. A., Kranton, R. E., 2008. Identity, supervision, and work groups. The American Economic Review 98 (2), 212-217.

Alt, J. E., Lowry, R. C., 2000. A dynamic model of state budget outcomes under divided partisan government. Journal of Politics 62 (4), 1035-1069.

Andreoni, J., 1990. Impure altruism and donations to public goods: A theory of warm-glow giving. The economic journal 100 (401), 464-477.

Archibald, R. B., Feldman, D., 2006. State higher education spending and the tax revolt. The Journal of Higher Education 77 (4), 618-644.

Arrow, K. J., 1972. Gifts and exchanges. Philosophy \& Public Affairs, 343-362.

Astin, A. W., 1977. Four critical years. effects of college on beliefs, attitudes, and knowledge.

Bagozzi, R. P., 1981. Attitudes, intentions, and behavior: A test of some key hypotheses. Journal of personality and social psychology 41 (4), 607.

Barrilleaux, C., Holbrook, T., Langer, L., 2002. Electoral competition, legislative balance, and american state welfare policy. American Journal of Political Science, 415-427.

Bartels, L. M., 2000. Partisanship and voting behavior, 1952-1996. American Journal of Political Science, 35-50.

Bender, B., Lott Jr, J. R., 1996. Legislator voting and shirking: A critical review of the literature. Public Choice 87 (1-2), 67-100.

Berry, W. D., Ringquist, E. J., Fording, R. C., Hanson, R. L., 1998. Measuring citizen and government ideology in the american states, 1960-93. American Journal of Political Science, $327-348$. 
Besley, T., Coate, S., 1997. An economic model of representative democracy. The Quarterly Journal of Economics 112 (1), 85-114.

Beyle, T., 2003. The institutional power ratings for the 50 governors of the united states. Thad Beyles Web Page, UNC.

Bianco, W. T., 1994. Trust: Representatives and constituents. University of Michigan Press.

Black, D., Newing, R. A., McLean, I., McMillan, A., Monroe, B. L., 1958. The theory of committees and elections. Springer.

Black, G. S., 1972. A theory of political ambition: Career choices and the role of structural incentives. American Political Science Review 66 (01), 144-159.

Breusch, T. S., Pagan, A. R., 1980. The lagrange multiplier test and its applications to model specification in econometrics. The Review of Economic Studies 47 (1), 239-253.

Brewer, M. B., 1979. In-group bias in the minimal intergroup situation: A cognitive-motivational analysis. Psychological bulletin 86 (2), 307.

Bronars, S. G., Lott Jr, J. R., 1997. Do campaign donations alter how a politician votes-or, do donors support candidates who value the same things that they do. Journal of Law and Economics 40, 317.

Cain, B., Ferejohn, J., Fiorina, M., 1987. The personal vote: Constituency service and electoral independence. Harvard University Press.

Cain, B. E., 1985. Assessing the partisan effects of redistricting. American Political Science Review 79 (2), 320-333.

Cameron, A. C., Miller, D. L., 2015. A practitioners guide to cluster-robust inference. Journal of Human Resources 50 (2), 317-372.

Carroll, S. J., 1994. Women as candidates in American politics. Indiana University Press.

Caselli, F., Morelli, M., 2004. Bad politicians. Journal of Public Economics 88 (3), 759-782.

Clotfelter, C. T., 2003. Alumni giving to elite private colleges and universities. Economics of Education review 22 (2), 109-120.

Dometrius, N. C., 1987. Changing gubernatorial power: The measure vs. reality. The Western Political Quarterly, 319-328. 
Downs, A., 1957. An economic theory of political action in a democracy. The journal of political economy, 135-150.

Ehrenberg, R. G., 2006. The perfect storm and the privatization of public higher education. Change: The Magazine of Higher Learning 38 (1), 46-53.

Fiorina, M. P., 1977. An outline for a model of party choice. American Journal of Political Science, 601-625.

Geer, J. G., 1996. From tea leaves to opinion polls: A theory of democratic leadership. Columbia University Press.

Gelman, A., King, G., 1994. Enhancing democracy through legislative redistricting. American Political Science Review 88 (3), 541-559.

Goette, L., Huffman, D., Meier, S., 2006. The impact of group membership on cooperation and norm enforcement: Evidence using random assignment to real social groups. American Economic Review 96 (2), 212-216.

Goldin, C., Katz, L. F., 1998. The shaping of higher education: the formative years in the united states, 1890 to 1940 .

Hausman, J. A., 1978. Specification tests in econometrics. Econometrica: Journal of the Econometric Society, 1251-1271.

Hiltonsmith, R., Draut, T., 2014. The great cost shift continues: State higher education funding after the recession. Dēmos.

Hoechle, D., et al., 2007. Robust standard errors for panel regressions with cross-sectional dependence. Stata Journal 7 (3), 281.

Hovey, H. A., 1999. State spending for higher education in the next decade: The battle to sustain current support. The National Center for Public Policy and Higher Education.

Huber, J. D., Shipan, C. R., Pfahler, M., 2001. Legislatures and statutory control of bureaucracy. American Journal of Political Science, 330-345.

Hutchison, T., James, K., 1988. Legislative budget procedures in the 50 states: A guide to appropriations and budget processes.

Hyman, H. H., Wright, C. R., 1979. Educations lasting effect on values. Univ. of Chicago, Chicago. 
Jacobs, L. R., Shapiro, R. Y., 2000. Politicians don't pander: Political manipulation and the loss of democratic responsiveness. University of Chicago Press.

Jaquette, O., Curs, B. R., 2015. Creating the out-of-state university: Do public universities increase nonresident freshman enrollment in response to declining state appropriations? Research in Higher Education 56 (6), 535-565.

Kingdon, J. W., 1989. Congressmen's voting decisions. University of Michigan Press.

Klarner, C. E., Berry, W. D., Carsey, T. M., Jewell, M., Niemi, R. G., Powell, L. W., Snyder, J., 2015. State legislative election returns (1967-2015). ICPSR 21480, 3938, and 8907.

Landa, J. T., 1994. Trust, ethnicity, and identity: beyond the new institutional economics of ethnic trading networks, contract law, and gift-exchange. University of Michigan Press.

Levitt, S. D., 1996. How do senators vote? disentangling the role of voter preferences, party affiliation, and senator ideology. The American Economic Review, 425-441.

Mael, F., Ashforth, B. E., 1992. Alumni and their alma mater: A partial test of the reformulated model of organizational identification. Journal of organizational Behavior 13 (2), 103-123.

Mayhew, D. R., 1974. Congress: The electoral connection. Yale University Press.

McLendon, M. K., Hearn, J. C., Mokher, C. G., 2009. Partisans, professionals, and power: The role of political factors in state higher education funding. The Journal of Higher Education 80 (6), 686-713.

Miller, A. H., Gurin, P., Gurin, G., Malanchuk, O., 1981. Group consciousness and political participation. American Journal of Political Science, 494-511.

Okunade, A. A., 2004. What factors influence state appropriations for public higher education in the united states? Journal of Education Finance, 123-138.

Osborne, M. J., Slivinski, A., 1996. A model of political competition with citizen-candidates. The Quarterly Journal of Economics 111 (1), 65-96.

Pascarella, E. T., Terenzini, P. T., 2005. How college affects students: A third decade of research. volume 2. Jossey-Bass, An Imprint of Wiley.

Peltzman, S., 1985. An economic interpretation of the history of congressional voting in the twentieth century. The American Economic Review 75 (4), 656-675. 
Petersen, M. A., 2009. Estimating standard errors in finance panel data sets: Comparing approaches. The Review of Financial Studies 22 (1), 435-480.

Piliavin, J. A., Charng, H.-W., 1990. Altruism: A review of recent theory and research. Annual review of sociology $16(1), 27-65$.

Rizzo, M. J., 2004. A (less than) zero sum game? state funding for public education: How public higher education institutions have lost.

Rose-Ackerman, S., 1996. Altruism, nonprofits, and economic theory. Journal of economic literature 34 (2), 701-728.

Rosenwasser, S. M., Seale, J., 1988. Attitudes toward a hypothetical male or female presidential candidate: A research note. Political Psychology, 591-598.

Saint-German, M. A., 1989. Does their difference make a difference? the impact of women on public policy in the arizona legislature. Social Science Quarterly 70 (4), 956.

Sapiro, V., 1983. The political integration of women: Roles, socialization, and politics. University of Illinois Press.

SHEEO, 2014. State support for higher education database instructions for fy 2015 grapevine and fy 2014 shef reports.

Simon, H. A., 1993. Altruism and economics. The American Economic Review 83 (2), 156-161.

Squire, P., Hamm, K. E., 2005. 101 chambers: Congress, state legislatures, and the future of legislative studies. Ohio State University Press.

Staiger, D. O., Stock, J. H., 1994. Instrumental variables regression with weak instruments.

Steinberg, R., 1987. Voluntary donations and public expenditures in a federalist system. The American Economic Review, 24-36.

Stimson, J. A., MacKuen, M. B., Erikson, R. S., 1995. Dynamic representation. American Political Science Review 89 (03), 543-565.

Stock, J. H., Wright, J. H., Yogo, M., 2002. A survey of weak instruments and weak identification in generalized method of moments. Journal of Business \& Economic Statistics 20 (4), 518-529.

Strathman, J. G., 1994. Migration, benefit spillovers and state support of higher education. Urban Studies 31 (6), 913-920. 
Tajfel, H., Turner, J. C., 1979. An integrative theory of intergroup conflict. The social psychology of intergroup relations 33 (47), 74 .

The Councils of State Governments, 2002. The Book of the States. CSG.

Toutkoushian, R. K., Hollis, P., 1998. Using panel data to examine legislative demand for higher education. Education Economics 6 (2), 141-157.

Tufte, E. R., 1973. The relationship between seats and votes in two-party systems. American Political Science Review 67 (2), 540-554.

Vote Smart, 2016. About vote smartHttp://votesmart.org/.

Washington, E., 2006. Candidate positioning in us house elections. NBER Working Paper No. 11924. 


\section{Appendices}

Table A: The Effect of Legislators with Ties to In-State Public or Community Institutions on System State Funding

\begin{tabular}{|c|c|c|}
\hline DV: $\log$ (System State Funding) & (1) & (2) \\
\hline In-State Pub/Comm & $\begin{array}{l}0.0448^{* *} \\
(0.0216)\end{array}$ & \\
\hline In-State Pub/Comm UH & & $\begin{array}{l}0.0400^{* *} \\
(0.0188)\end{array}$ \\
\hline In-State Pub/Comm LH & & $\begin{array}{c}0.0166 \\
(0.0204)\end{array}$ \\
\hline Republican & $\begin{array}{c}0.0243 \\
(0.0198)\end{array}$ & \\
\hline Republican UH & & $\begin{array}{c}0.0101 \\
(0.0176)\end{array}$ \\
\hline Republican LH & & $\begin{array}{c}0.0194 \\
(0.0212)\end{array}$ \\
\hline Female & $\begin{array}{c}0.0125 \\
(0.0119)\end{array}$ & \\
\hline Female UH & & $\begin{array}{c}0.00478 \\
(0.0106)\end{array}$ \\
\hline Female LH & & $\begin{array}{c}0.0343^{* *} \\
(0.0146)\end{array}$ \\
\hline Governor In-State Public & $\begin{array}{c}-0.00919 \\
(0.00708)\end{array}$ & $\begin{array}{c}-0.00881 \\
(0.00641)\end{array}$ \\
\hline Governor Republican & $\begin{array}{r}-0.00595 \\
(0.00657) \\
(0.00647)\end{array}$ & $\begin{array}{r}-0.00745 \\
(0.00640) \\
(0.00634)\end{array}$ \\
\hline $\begin{array}{l}\text { Controls } \\
\text { Year FE } \\
\text { State FE } \\
\text { Err. Clustered by State }\end{array}$ & $\begin{array}{l}\text { Yes } \\
\text { Yes } \\
\text { Yes } \\
\text { Yes }\end{array}$ & $\begin{array}{l}\text { Yes } \\
\text { Yes } \\
\text { Yes } \\
\text { Yes }\end{array}$ \\
\hline $\begin{array}{l}\text { No. of Observations } \\
\text { No. of States } \\
\text { Adjusted-R } R^{2}\end{array}$ & $\begin{array}{l}650 \\
50 \\
0.994\end{array}$ & $\begin{array}{l}637 \\
49 \\
0.994\end{array}$ \\
\hline
\end{tabular}


Table B: The Effect of Legislator School Ties on System State Funding






\section{A. Instrumental-Variable Estimation}

Given the potential endogeneity of legislators' college ties, an ideal experiment for testing our conceptual framework would be to randomly assign school ties to our sample of legislators and see how that affects state funding for higher education. Because this approach is clearly infeasible, we test the robustness of our specifications through an IV estimation. Based on the assumption that unobserved but fixed factors influence voters' choices for the state legislature, our fixed-effects specification controls for both unobserved and observed time-invariant state-level factors. To the extent that this assumption does not hold - that is, within-state variation in the education of elected legislators over time is endogenous - we leverage exogenous variation in the public institution's legislative district as an IV for the share of alumni legislators representing the legislative district containing their alma mater campus, in-district campus alum.

$$
\begin{gathered}
\text { Campus State Funding } g_{i j t}=\beta_{0}+\beta_{1}(\text { Campus Alums })_{i j t}+\beta_{2}(\text { Controls })_{i j t}+\mu_{i j t}, \\
\text { Campus Alums } s_{i j t}=\delta_{0}+\delta_{1}(\text { Redistricted })_{i j t}+\delta_{2}(\text { Controls })_{i j t}+v_{i j t} .
\end{gathered}
$$

Conceptually, we exploit the fact that Congressional and state legislative district lines are redrawn every 10 years in the U.S. based on Census population estimates. Following the release of the latest Census data in December 2010, 40 states implemented new district lines over the next two years, meaning $33 \%$ of public institutions in our sample, or 166 out of 496 total, switched to a different legislative district between 2011 and 2012. ${ }^{15}$ Changes in the boundaries of state legislative districts should be a plausible instrument because these changes would directly alter the share of alums representing an institution's legislative district, while remaining uncorrelated with residuals. Legislative redistricting, to our knowledge, does not have any direct effect on state funding for higher education, and our data reflect this lack of association $(r=0.016, p<0.20)$. Moreover, scholars argue legislative redistricting, including gerrymandering, is often motivated either by incumbent protection or partisan advantage; however, neither has been known to have causal implications on funding outcomes (e.g., Cain, 1985; Gelman and King, 1994; Tufte, 1973). Redistricting, therefore, should satisfy the exclusion restriction.

\footnotetext{
${ }^{15}$ Both chambers' legislative districts (e.g., Senate and House representation) changed for $11 \%$ of our public institutions, $17 \%$ of our public institutions experienced a change only in the lower chambers legislative district, and only $5 \%$ experienced a change in the upper chamber representation, leaving $67 \%$ of public institutions unaffected by redistricting.
} 
Table C presents the results from our IV estimation. As before, the dependent variable campus state funding - represents an allocation of state funding for a specific institution, or for a specific campus in the case of multi-campus universities. Our main independent variable - indistrict campus alum - measures the share of publicly educated alums representing their alma mater's legislative district. State fixed effects are used for all specifications. Although standard errors are clustered by campus to address serial correlation, the analyses below do not employ year or campus fixed effects, because we want to leverage across-group variation to estimate the effect of in-district campus alum on campus state funding, given the redistricting shock of 2011 and 2012. That is, we only observe one change in district boundaries, which would be completely soaked up by the campus-year fixed effects.

In Table $\mathrm{C}$, the instrument - redistricted - is an indicator for whether the legislative district of a given public institution's campus changed for either legislative chamber. The relevance of the instrument is confirmed in the first-stage regression shown in Specification 2. The first-stage results show a statistically significant, negative association between redistricted and in-district campus alum even after controlling for the exogenous regressors (coefficient $=-0.00142^{* * *}$ ); this reflects the possibility that voters from districts housing state institutions deliberately elect alums to advance their interests, whereas the redistricting breaks this direct, endogenous link and allows for our robustness check. This coefficient is also statistically different from zero, but a relatively low F-statistic for the joint significance test of the first-stage coefficients suggests a potentially weak instrument $(F=10.81, p<0.001)$. Given one endogenous regressor, however, our IV estimates should be reliable because the F-statistic slightly exceeds the critical value of 10.22 (Staiger and Stock, 1994; Stock et al., 2002). Specification 1 shows that alums representing their alma mater's legislative district, in-district campus alum, are positively associated with campus state funding. This positive relationship remains significant when instrumented by redistricted, as seen in the second-stage IV estimation in Specification 3. A much larger coefficient in Specification 3 relative to Specification 1 is likely driven by our relatively weak instrument, or more specifically, by a weak correlation between the instrument and the endogenous regressor, which is also reflected in the large standard errors reported in Specification 3. 
Table C: Instrumental-Variable Estimation

\begin{tabular}{|c|c|c|c|}
\hline & $(1)$ & $(2)$ & $(3)$ \\
\hline DV: $\log ($ Campus State Funding) & OLS & IV: 1st Stage & IV: 2nd Stage \\
\hline In-District Campus Alum & $\begin{array}{l}2.356^{* *} \\
(0.996)\end{array}$ & & $\begin{array}{l}141.3^{* * *} \\
(44.72)\end{array}$ \\
\hline Redistricted & $\begin{array}{r}-0.119^{* * *} \\
(0.00942)\end{array}$ & $\begin{array}{c}-0.00165^{* * *} \\
(0.000500)\end{array}$ & \\
\hline Controls & Yes & Yes & Yes \\
\hline Year FE & No & No & No \\
\hline State FE & Yes & Yes & Yes \\
\hline Err. Clustered by Campus & Yes & Yes & Yes \\
\hline No. of Observations & 6448 & 6448 & 6448 \\
\hline No. of Campuses & 496 & 496 & 496 \\
\hline
\end{tabular}


Table D: Correlation Matrix for State-Level Variables

\begin{tabular}{|c|c|c|c|c|c|c|c|c|c|c|c|c|c|c|c|c|c|c|c|c|c|c|}
\hline & 1 & 2 & 3 & 4 & 5 & 6 & 7 & 8 & 9 & 10 & 11 & 12 & 13 & 14 & 15 & 16 & 17 & 18 & 19 & 20 & 21 & 22 \\
\hline 1 & 1.00 & & & & & & & & & & & & & & & & & & & & & \\
\hline 2 & $0.48^{* * *}$ & 1.00 & & & & & & & & & & & & & & & & & & & & \\
\hline 3 & $0.22^{* * *}$ & $0.73^{* * *}$ & 1.00 & & & & & & & & & & & & & & & & & & & \\
\hline 4 & $0.31^{* * *}$ & $0.37^{* * *}$ & $-0.34^{* * *}$ & 1.00 & & & & & & & & & & & & & & & & & & \\
\hline 5 & $0.17^{* * *}$ & 0.04 & -0.03 & $-0.17^{* * *}$ & 1.00 & & & & & & & & & & & & & & & & & \\
\hline 6 & 0.02 & $-0.87^{* * *}$ & $-0.71^{* * *}$ & $-0.25^{* * *}$ & 0.05 & 1.00 & & & & & & & & & & & & & & & & \\
\hline 7 & -0.00 & $-0.64^{* * *}$ & $-0.39^{* * *}$ & $-0.37^{* * *}$ & $0.11^{* *}$ & $0.73^{* * *}$ & 1.00 & & & & & & & & & & & & & & & \\
\hline 8 & 0.05 & $-0.67^{* * *}$ & $-0.67^{* * *}$ & -0.01 & -0.02 & $0.79^{* * *}$ & $0.16^{* * *}$ & 1.00 & & & & & & & & & & & & & & \\
\hline 9 & $-0.29^{* * *}$ & $-0.26^{* * *}$ & -0.08 & $-0.25^{* * *}$ & -0.02 & $0.14^{* * *}$ & 0.04 & $0.09^{*}$ & 1.00 & & & & & & & & & & & & & \\
\hline 10 & -0.05 & 0.01 & $0.09^{*}$ & $-0.16^{* * *}$ & $0.17^{* * *}$ & -0.04 & $0.19^{* * *}$ & $-0.23^{* * *}$ & 0.08 & 1.00 & & & & & & & & & & & & \\
\hline 11 & $-0.16^{* * *}$ & $-0.44^{* * *}$ & $-0.41^{* * *}$ & -0.07 & 0.03 & $0.42^{* * *}$ & $0.12^{* *}$ & $0.49^{* * *}$ & 0.07 & $-0.22^{* * *}$ & 1.00 & & & & & & & & & & & \\
\hline 12 & -0.07 & $0.17^{* * *}$ & $0.31^{* * *}$ & $-0.15^{* * *}$ & -0.07 & $-0.24^{* * *}$ & $-0.12^{* *}$ & $-0.24^{* * *}$ & 0.02 & $0.13^{* *}$ & $-0.18^{* * *}$ & 1.00 & & & & & & & & & & \\
\hline 13 & 0.06 & $0.13^{* *}$ & $0.14^{* * *}$ & -0.01 & -0.06 & $-0.11^{* *}$ & -0.03 & $-0.14^{* * *}$ & 0.02 & $0.17^{* * *}$ & $-0.20^{* * *}$ & 0.05 & 1.00 & & & & & & & & & \\
\hline 14 & $0.36^{* * *}$ & $0.36^{* * *}$ & $0.15^{* * *}$ & $0.26^{* * *}$ & $0.12^{* *}$ & $-0.21^{* * *}$ & $-0.20^{* * *}$ & $-0.11^{* *}$ & $-0.15^{* * *}$ & 0.02 & -0.04 & 0.05 & 0.04 & 1.00 & & & & & & & & \\
\hline 15 & $0.40^{* * *}$ & $0.37^{* * *}$ & $0.08^{*}$ & $0.36^{* * *}$ & $0.14^{* * *}$ & $-0.19^{* * *}$ & $-0.19^{* * *}$ & $-0.10^{*}$ & $-0.21^{* * *}$ & $0.13^{* * *}$ & -0.07 & -0.01 & 0.03 & $0.66^{* * *}$ & 1.00 & & & & & & & \\
\hline 16 & $0.36^{* * *}$ & $0.35^{* * *}$ & $0.12^{* *}$ & $0.28^{* * *}$ & $0.14^{* * *}$ & $-0.20^{* * *}$ & $-0.20^{* * *}$ & $-0.09^{*}$ & $-0.17^{* * *}$ & 0.05 & 0.02 & 0.01 & 0.03 & $0.96^{* * *}$ & $0.75^{* * *}$ & 1.00 & & & & & & \\
\hline 17 & $0.36^{* * *}$ & $0.32^{* * *}$ & 0.02 & $0.38^{* * *}$ & $0.14^{* * *}$ & $-0.16^{* * *}$ & $-0.22^{* * *}$ & -0.03 & $-0.16^{* * *}$ & -0.02 & 0.04 & -0.04 & -0.02 & $0.94^{* * *}$ & $0.71^{* * *}$ & $0.96^{* * *}$ & 1.00 & & & & & \\
\hline 18 & $0.38^{* * *}$ & $0.33^{* * *}$ & 0.04 & $0.36^{* * *}$ & $0.11^{* *}$ & $-0.16^{* * *}$ & $-0.20^{* * *}$ & -0.05 & $-0.17^{* * *}$ & 0.03 & 0.02 & -0.02 & 0.03 & $0.96^{* * *}$ & $0.77^{* * *}$ & $0.97^{* * *}$ & $0.97^{* * *}$ & 1.00 & & & & \\
\hline 19 & $0.37^{* * *}$ & $0.35^{* * *}$ & 0.04 & $0.39^{* * *}$ & $0.12^{* *}$ & $-0.19^{* * *}$ & $-0.23^{* * *}$ & -0.06 & $-0.18^{* * *}$ & 0.01 & 0.01 & -0.04 & -0.00 & $0.93^{* * *}$ & $0.74^{* * *}$ & $0.97^{* * *}$ & $0.99^{* * *}$ & $0.97^{* * *}$ & 1.00 & & & \\
\hline 20 & $0.46^{* * *}$ & $0.47^{* * *}$ & $0.11^{* *}$ & $0.44^{* * *}$ & $0.16^{* * *}$ & $-0.27^{* * *}$ & $-0.28^{* * *}$ & $-0.14^{* * *}$ & $-0.16^{* * *}$ & 0.04 & -0.01 & 0.03 & -0.04 & $0.75^{* * *}$ & $0.79^{* * *}$ & $0.79^{* * *}$ & $0.78^{* * *}$ & $0.81^{* * *}$ & $0.79^{* * *}$ & 1.00 & & \\
\hline 21 & $0.10^{* *}$ & $-0.32^{* * *}$ & $-0.57^{* * *}$ & $0.35^{* * *}$ & $-0.11^{* *}$ & $0.42^{* * *}$ & -0.00 & $0.62^{* * *}$ & -0.02 & $-0.23^{* * *}$ & $0.52^{* * *}$ & $-0.30^{* * *}$ & -0.07 & 0.04 & $0.13^{* * *}$ & $0.10^{*}$ & $0.16^{* * *}$ & $0.16^{* * *}$ & $0.14^{* * *}$ & $0.12^{* *}$ & 1.00 & \\
\hline 22 & $0.23^{* * *}$ & $0.10^{*}$ & 0.03 & 0.05 & $0.19^{* * *}$ & 0.01 & 0.03 & -0.00 & $-0.12^{* *}$ & -0.04 & 0.03 & 0.05 & -0.06 & $0.21^{* * *}$ & $0.30^{* * *}$ & $0.27^{* * *}$ & $0.23^{* * *}$ & $0.22^{* * *}$ & $0.26^{* * *}$ & $0.32^{* * *}$ & -0.07 & 1.00 \\
\hline
\end{tabular}

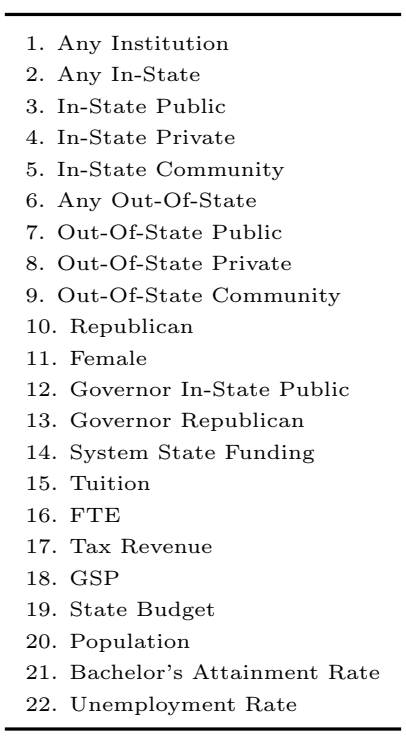


Table E: Correlation Matrix for Campus-Level Variable

\begin{tabular}{|c|c|c|c|c|c|c|c|c|c|c|c|c|c|}
\hline & 1 & 2 & 3 & 4 & 5 & 6 & 7 & 8 & 9 & 10 & 11 & 12 & 13 \\
\hline 1. In-State Public Campus Alum & 1.00 & & & & & & & & & & & & \\
\hline 2. In-State Public Campus Alum & $-0.32^{* * *}$ & 1.00 & & & & & & & & & & & \\
\hline 3. In-District Campus Alum & $0.28^{* * *}$ & $0.11^{* * *}$ & 1.00 & & & & & & & & & & \\
\hline 4. Nearby-District Campus Alum & $0.39^{* * *}$ & $-0.04^{* * *}$ & $0.23^{* * *}$ & 1.00 & & & & & & & & & \\
\hline 5. Other-District Campus Alum & $0.97^{* * *}$ & $-0.36^{* * *}$ & $0.12^{* * *}$ & $0.19^{* * *}$ & 1.00 & & & & & & & & \\
\hline 6. Campus State Funding & $0.47^{* * *}$ & $-0.21^{* * *}$ & $0.12^{* * *}$ & $0.26^{* * *}$ & $0.44^{* * *}$ & 1.00 & & & & & & & \\
\hline 7. Net Assets & $0.35^{* * *}$ & $-0.11^{* * *}$ & $0.08^{* * *}$ & $0.12^{* * *}$ & $0.34^{* * *}$ & $0.54^{* * *}$ & 1.00 & & & & & & \\
\hline 8. Institutional Support & $0.40^{* * *}$ & $-0.21^{* * *}$ & $0.11^{* * *}$ & $0.21^{* * *}$ & $0.38^{* * *}$ & $0.71^{* * *}$ & $0.77^{* * *}$ & 1.00 & & & & & \\
\hline 9. Academic Support & $0.42^{* * *}$ & $-0.19^{* * *}$ & $0.09^{* * *}$ & $0.22^{* * *}$ & $0.39^{* * *}$ & $0.65^{* * *}$ & $0.76^{* * *}$ & $0.82^{* * *}$ & 1.00 & & & & \\
\hline 10. Tuition and Fees & $0.48^{* * *}$ & $-0.21^{* * *}$ & $0.17^{* * *}$ & $0.26^{* * *}$ & $0.44^{* * *}$ & $0.66^{* * *}$ & $0.76^{* * *}$ & $0.81^{* * *}$ & $0.83^{* * *}$ & 1.00 & & & \\
\hline 11. Federal Grants & $0.42^{* * *}$ & $-0.19^{* * *}$ & $0.08^{* * *}$ & $0.23^{* * *}$ & $0.40^{* * *}$ & $0.61^{* * *}$ & $0.83^{* * *}$ & $0.79^{* * *}$ & $0.82^{* * *}$ & $0.75^{* * *}$ & 1.00 & & \\
\hline 12. State Grants & $0.13^{* * *}$ & $-0.16^{* * *}$ & 0.02 & $0.07^{* * *}$ & $0.12^{* * *}$ & $0.39^{* * *}$ & $0.27^{* * *}$ & $0.34^{* * *}$ & $0.43^{* * *}$ & $0.42^{* * *}$ & $0.38^{* * *}$ & 1.00 & \\
\hline 13. Population & $-0.03^{*}$ & $-0.05^{* * *}$ & $-0.04^{* *}$ & $0.07^{* * *}$ & $-0.04^{* *}$ & $0.24^{* * *}$ & $0.06^{* * *}$ & $0.18^{* * *}$ & $0.14^{* * *}$ & $0.11^{* * *}$ & $0.11^{* * *}$ & $0.26^{* * *}$ & 1.00 \\
\hline
\end{tabular}

${ }^{*} p<0.05,{ }^{* *} p<0.01,{ }^{* * *} p<0.001$ 